\title{
A Birth Cohort Analysis of First Employment Spells*
}

\author{
Luke Ignaczak \\ Department of Economics, Carleton University, Ottawa, Canada \\ Email: luke.ignaczak@carleton.ca
}

Received 9 April 2014; revised 17 May 2014; accepted 25 May 2014

Copyright (C) 2014 by author and Scientific Research Publishing Inc.

This work is licensed under the Creative Commons Attribution International License (CC BY).

http://creativecommons.org/licenses/by/4.0/

(c) (i) Open Access

\begin{abstract}
The duration of the first employment spell of workers across five different birth cohorts is investigated using pooled data from the 15th and 20th cycles of the Canadian General Social Survey. These retrospective surveys contain information that spans well over the last half of the 20th century. The data are benchmarked against the Labour Force Survey to emphasize the distinct nature of employment spells vis-a-vis job tenures as commonly used in the literature. Overall, this paper contributes to the debate of employment stability by analyzing the differences between job and employment durations and showing that successive cohorts of workers have had increasingly shorter first employment durations. The analysis finds cohort effects which play a significant role in explaining declining employment tenure. The cohort effects can be seen as a proxy for a number of socio-economic factors that affect the hazard of separation from employment. Separate analysis is completed for men and women by birth cohort. This pattern of declining tenure has occurred for both men and women, but the decline has been far more prominent for men. For men, macroeconomic factors affect the hazard more strongly in more recent cohorts, which is consistent with recessionary periods generating decreasing employment stability across cohorts. For women, cohort effects are consistent with the increasing generosity of maternity leave provisions through Unemployment Insurance.
\end{abstract}

\section{Keywords}

Employment Stability, Duration Models

\section{Introduction}

There is a broadly held notion that job stability has decreased over time in industrialized countries, particularly

*The data used for this study were provided by Statistics Canada through the Carleton Ottawa Outaouais Local Research Data Centre (COOL RDC). All errors are the responsibility of the author. 
over the last quarter of the twentieth century. However, the evidence on the topic is mixed and criticism is often leveled at weakness in the data. In order to further examine this issue, this study will focus on the first employment tenure of workers. Data from the 15th ad 20th cycles of the Canadian General Social Survey (GSS) will be used to analyze the first employment spells of individuals by birth cohort. These data are useful because it can reasonably cover over fifty years of history and can readily generate five ten-year birth cohorts (1930-1939, 1940-1949, 1950-1959, 1960-1969, and 1970-1979) for comparison. To emphasize the differences between the employment spells found in the GSS and the job spells commonly used in the literature, a comparison with the Canadian Labour Force Survey (LFS) will be performed. Using a semiparametric hazard model, it can be inferred that socio-demographic factors, likely stemming from changing social institutions, contribute to the declines in first employment tenures over the latter half of the twentieth century.

Studies from the United States which deal with the topic of job tenure such as Hall [1], Diebold et al. [2] and Farber [3] and Jaeger and Stevens [4] found that jobs remained stable between the 1970s and early 1990s. Conversely, using the same data Swinnerton and Wial [5], Ureta [6] and Rose [7] showed that there had been some declines in stability over the 1980s. More recently, Farber [8] using a birth cohort approach found an increase in short-tenure positions and declines in long-term employment relationships. In particular, Farber's results indicate that mean employment tenure for men has deteriorated by 50 percent after controlling for education between the 1914 and the 1975 birth cohorts. For women the declines were smaller.

In the Canadian context, the literature on job stability has largely shown that employment is stable and declines in job stability are largely counter-cyclical. This was largely the case in Green and Riddell [9], Picot, Heisz, and Nakamura [10] and Heisz [11]. Interestingly, the newest in this line of studies, Brochu [12] has found consistent increases in job stability stemming from increases in the tenures of workers with low initial job tenure. Conversely, Ignaczak and Voia [13] found evidence of decreasing stability through the decline in employment tenure, particularly for men, over the second half of the twentieth century. On this topic, Christofides and McKenna [14], using data from the 1986-1987 and 1988-1990 Labour Market Activity Study (LMAS) found that older, married heads of households with children, white-collar workers, and individuals in full-time, unionized jobs with pension plans were less likely to leave employment.

It should be noted that one reason to be concerned with first employment spells is that employment tenure displays a high level of persistence. Because of this it is important to understand the initial job prospects of individuals. Furthermore, looking back over a longer period helps us to identify the differences in stability that may not be apparent in shorter-term analysis. The rest of this paper is structured in the following way: Section 2 discusses the data and compares job tenures to employment tenures while Section 3 lays out the empirical methodology and results. Finally, Section 4 concludes.

\section{Data}

This section is laid out into two components. The first part looks at the data used for the estimation of the model and some of the features of the dataset. The second part describes areas of commonality between the GSS data used in this study and the LFS which is commonly used to examine issues of job stability in Canada.

\subsection{The Canadian General Social Survey}

The 15th and 20th cycles of the GSS are used to produce estimates of employment tenure. The two surveys were conducted throughout 2001 and 2006 and contain 24,310 and 22,435 records respectively. These datasets are pooled as independent samples and yield 17,153 usable records for the purpose of estimation. The variable of interest is the duration of the first employment spell for those who have completed their studies. Table 1 provides weighted summary statistics from the pooled surveys with unweighted observation counts. Half of the sample is composed of women, immigrants constitute twenty percent of the sample and just over one-quarter of respondents were married before the employment spell under observation began. Just under half of the usable spells come from the 2001 GSS and the largest cohorts are those of the 1960s and 1950s respectively. It should be noted that the age that studies ended has fewer observations than most variables, this fact will limit the sample size due to dropped observations when conditioning on school completion.

The analysis is based on groupings of ten-year birth cohorts. To determine whether the first employment spell has declined in length over different birth cohorts, the first spell of employment of individuals that were born in a particular decade are compared to one another. In the GSS, respondents retrospectively identify up to five 
Table 1. Summary table.

\begin{tabular}{|c|c|c|c|c|c|}
\hline Variable & Obs. & Mean & Std. dev. & Min & Max \\
\hline Age & 44,226 & 41.6 & 15.844 & 15 & 77 \\
\hline Year born & 44,226 & 1963 & 15.887 & 1930 & 1992 \\
\hline Male & 44,226 & 0.499 & 0.5 & 0 & 1 \\
\hline Age studies end & 31,976 & 24.3 & 7.803 & 10 & 75 \\
\hline Immigrant & 44,226 & 0.201 & 0.401 & 0 & 1 \\
\hline Youth & 44,226 & 0.713 & 0.452 & 0 & 1 \\
\hline Age work began & 37,482 & 20.782 & 5.256 & 10 & 63 \\
\hline Part-time emp. & 44,226 & 0.073 & 0.261 & 0 & 1 \\
\hline Edu university & 43,570 & 0.219 & 0.413 & 0 & 1 \\
\hline Edu comm college & 43,570 & 0.262 & 0.44 & 0 & 1 \\
\hline Edu high school & 43,570 & 0.31 & 0.462 & 0 & 1 \\
\hline Edu less than hs & 43,570 & 0.21 & 0.407 & 0 & 1 \\
\hline Married & 44,226 & 0.256 & 0.436 & 0 & 1 \\
\hline Parental & 44,226 & 0.109 & 0.312 & 0 & 1 \\
\hline Work related & 44,226 & 0.094 & 0.292 & 0 & 1 \\
\hline Emp duration & 37,482 & 14.962 & 14.325 & 0 & 65 \\
\hline UR gap & 44,221 & -0.109 & -0.799 & -2.16 & 2.48 \\
\hline Cohort 1930-1939 & 44,226 & 0.089 & 0.285 & 0 & 1 \\
\hline Cohort 1940-1949 & 44,226 & 0.132 & 0.338 & 0 & 1 \\
\hline Cohort 1950-1959 & 44,226 & 0.194 & 0.395 & 0 & 1 \\
\hline Cohort 1960-1969 & 44,226 & 0.216 & 0.412 & 0 & 1 \\
\hline Cohort 1970-1979 & 44,226 & 0.18 & 0.384 & 0 & 1 \\
\hline Cohort 1980-1989 & 44,226 & 0.16 & 0.367 & 0 & 1 \\
\hline GSS 2001 & 44,226 & 0.476 & 0.499 & 0 & 1 \\
\hline
\end{tabular}

work episodes over their life course. This information is sufficient to extract details on the duration of the first employment spell for individuals. Exit from employment is identified by the exit date provided or by the year of retirement if a date is not provided. Data is dropped when respondents refuse to answer, don't know or are not asked. Furthermore, employment spells of immigrants before arrival in Canada and individuals whose studies are incomplete are also dropped. Data for ongoing spells, those which have started but not ended, are retained for estimation as they can contribute to the hazard up to the point of censoring. As in Ignaczak and Voia [13], employment durations were constructed by obtaining the year in which the first spell ended and subtracting it from the year it began. Employment spells for all classes of workers are included in the study.

It should be recognized that the data obtained focuses on work interruptions of three months or more. The data does not permit us to verify whether the interruption ended with a return to the same employer or a new employer. Hence, we must focus on employment stability rather than job stability. Many respondents reported interruptions of less than three months, possibly due to a change of employer being interpreted as an interruption despite the lack of a three month break-these were retained in the sample as the topic of interest is work sepa- 
rations regardless of length.

Ignaczak and Voia [13] provide a detailed analysis of the data including the potential problems associated with using this retrospective data, the results will be briefly summarized below. Most of the tests performed in that paper on the data indicate that the sample did not suffer from an inordinate degree of bias due to sample selection or memory effects. One potential data problem that is worth stating here is the issue of how mortality could generate a peculiar form of attrition bias in the sample. This would occur because any potential respondent who worked in the past but died before the retrospective survey date would fall out of the sample entirely. The survey samples of the GSS conform to census population benchmarks, so that the age distribution in the GSS matches the Canadian population at the time of the surveys. Because the youngest individual in the pool of usable spells was born in 1930 that individual would be at most 76 years of age in 2006 (or 71 in 2001). Although this is somewhat higher than life expectancy at age 20 in 1951 (71 for men and 74 for women), the 1930s birth cohort were selected as the earliest possible starting point for the analysis. The response rates in the GSS were sufficiently high so that selection bias was assessed as posing a fairly remote possibility. Issues common to retrospective surveys, such as the heaping and memory effects described in Torelli and Trivellato [15], were either corrected for through aggregation or addressed by testing. Recall errors are date and saliency-dependent and are likely to remain somewhat problematic with this data; if workers forget an employment spell entirely (likely an earlier and shorter spell) it would bias down the number of short duration spells. Tests for forward telescoping were performed on these datasets by comparing responses on employment durations between the 15th and 20th cycles of the survey, no clear pattern emerged from those tests for that 5-year interval.

The covariates used to analyze the first employment tenure will focus on some socio-economic characteristics available within the dataset. These are gender, age at which the spell began, marital status prior the employment spell, whether the respondent immigrated to Canada, was in part- or full-time employment, whether they left the job for work-related reasons or for parental leave as well as a series of birth cohort effects. The deviation of the unemployment rate from a Hoddrick-Prescott filtered trend unemployment rate is used to capture macroeconomic effects at the end of the employment spell. Furthermore, we use a series of dummy variables to capture the effect of educational attainment on the hazard. The reasons for departure as well as the cohorts which are more heavily influenced by declines can help identify the periods in which the changes in the hazard of leaving employment coincide with institutional changes.

\subsection{Benchmarking Employment Tenures with Job Tenures}

It is common in the literature to use retention rates to test for the presence job stability over time. Hall [1] and Farber [3] are examples of this approach using American data. In Canada, Heisz [11] and, more recently, Brochu [12] have used the LFS to examine the stability of employment tenures over a thirty-year horizon. The most recent of the above papers argues that job stability has increased over time owing largely to the growth in stability of the lowest tenured jobs. In his paper the author argues that the LFS constitutes a superior source of information for the construction of retention rates than does the US Current Population Survey (CPS) owing to the consistency and frequency of the questions on job tenure.

In Ignaczak and Voia [13] it was shown using the GSS that employment tenures were declining for successive generations of Canadian workers over the second half of the twentieth century. While this evidence is not directly at odds with the key findings in Brochu [12], whose key results occur largely after the turn of the century, it does run contrary to the findings of overall stability found in much of the literature. One key source of divergence between these results is likely to be found in the data definitions.

Brochu [12] describes the questions asked of individuals in the LFS as related to the current job they hold. These jobs are focused on the positions held with the current employer. The retrospective question relates to when the current job started. Ignaczak and Voia [13] describe the employment spell used in their study as related to a retrospective question regarding an uninterrupted period of work after which a minimum 3 month break occurs. These uninterrupted employment spells can consist of a series of jobs or of a temporary, albeit lengthy, interruption in a single job. While it is likely that in a large number of cases these job and employment spells correspond, it is likely that there are also a significant number of cases where they do not. It is also likely that an employment spell is likely to be longer for individuals than a job spell when they do not correspond. That is, any continuous period of employment is more likely to contain a series of jobs rather than seeing a single job split into many employment spells divided by intervals of three months or greater. 
To compare these datasets over the 1976 to 2001 interval, one year retention rates (RR) were constructed for core-aged workers using the both the LFS and the GSS. The LFS retention rates, depicted in Equations (1) and (2) below, were constructed as the sum of the last periods employment $\left(\mathrm{EMP}_{t-1}\right)$ minus the jobs lost to attrition $\left(\mathrm{ATR}_{t}\right)$ by the end of the period, over the corresponding employment pool built using a synthetic birthcohort approach on appropriately weighted $\left(w_{i}\right)$ data. Given that age $(a)$ and tenure $(j)$ information is captured by the LFS consistently each year, using appropriately lagged variables across time will capture the retention behaviour of each birth cohort grouping (up to international mobility while in an ongoing job spell).

$$
\begin{gathered}
\mathrm{RR}_{t}^{\mathrm{LFS}}=100 \times\left[1-\left(\frac{\sum_{j=1}^{J} \mathrm{ATR}_{t, j}^{\mathrm{LFS}}}{\sum_{j=1}^{J} \mathrm{EMP}_{j-1, t-1}^{\mathrm{LFS}}}\right)\right] \\
\operatorname{ATR}_{t, j}^{\mathrm{LFS}}=\sum_{a=25}^{54}\left[\sum_{i=1}^{N}\left(w_{i, t} \times \mathrm{EMP}_{i, a, t, j}^{\mathrm{LFS}}\right)-\sum_{i=1}^{N}\left(w_{k, t-1} \times \mathrm{EMP}_{k, a-1, t-1, j-1}^{\mathrm{LFS}}\right)\right], k \neq i
\end{gathered}
$$

For the GSS, the construction of the one year retention rates in Equations (3) and (4) was slightly more problematic given the entirely retrospective nature of the dataset. All employment spells were used in the construction of retention rates. Employment estimates were produced by selecting employment spells which began on or before the reference year and ended on or before that year. The data are weighted by the 2001 or 2006 survey weights within the GSS and hence employment estimates outside of those years are likely to be weighted improperly to some degree. Overlapping spells by the same individual were dropped from the sample when computing employment but were retained for computing attrition. Attrition numbers were obtained by computing when each individual leaves the current employment spell. GSS retention rates, described below, are obtained by subtracting the ratio of the sums of attrition and the previous period's employment from 1 and multiplying by 100 .

$$
\begin{gathered}
\mathrm{RR}_{t}^{\mathrm{GSS}}=100 \times\left[1-\left(\frac{\sum_{j=1}^{J} \mathrm{ATR}_{t, j}^{\mathrm{GSS}}}{\sum_{j=1}^{J} \mathrm{EMP}_{j-1, t-1}^{\mathrm{GSS}}}\right)\right] \\
\operatorname{ATR}_{t, j}^{\mathrm{GSS}}=\sum_{a=25}^{54}\left[\sum_{i=1}^{N} w_{i} \times\left(\mathrm{EMP}_{i, a, t, j}^{\mathrm{GSS}}-\mathrm{EMP}_{i, a-1, t-1, j-1}^{\mathrm{GSS}}\right)\right]
\end{gathered}
$$

Using the same methods five and ten year retention rates were also constructed. Comparisons of one, five and ten year retention rates as well as total employment between the GSS and LFS can be seen in Figure 1. In panel a) Core employment is notably larger in the LFS-based sample than in the GSS-based sample, likely due to the selection of only those who have completed their studies. Moreover, the LFS employment sample contains pronounced cyclicality around the recessions of 1982 and 1991. The GSS employment estimate, while possessing some small cyclical movements, can largely be seen as a simple trend in employment. Up until the mid-1990s GSS employment tends to grow faster than its LFS-based counterpart but grows more slowly thereafter. It should be noted that the LFS sample pools two survey samples from each year (one from March and one from September) while the GSS-based sample pools together the 2001 and 2006 retrospective surveys. Hence, the LFS sample will report approximately twice the employment for core-aged workers in each year and the GSS sample will report the pooling of the 2001 and 2006 Canadian population and the corresponding recollection of their employment histories.

Comparative one, five and ten year retention rates are shown in panels (b), (c) and (d) of Figure 1. The first thing to note is that retention rates in the GSS sample are above those seen in the LFS sample. This corresponds to the fact that employment spells may be composed of multiple job spells. Secondly, there is a divergence in the trends between the LFS and GSS-based rates. The GSS rates have weakly counter-cyclical negative trends while the LFS-based rates seem to show weakly positive trend growth with a pronounced counter-cyclical aspect. Figure 2 compares the retention rates for both the GSS-based and the LFS-based estimates. It should be noted that in both cases one-year retention rates exceed the five-year retention rate by a wide margin and that the fiveyear retention rates exceed the ten-year retention rates by a significantly narrower margin. 


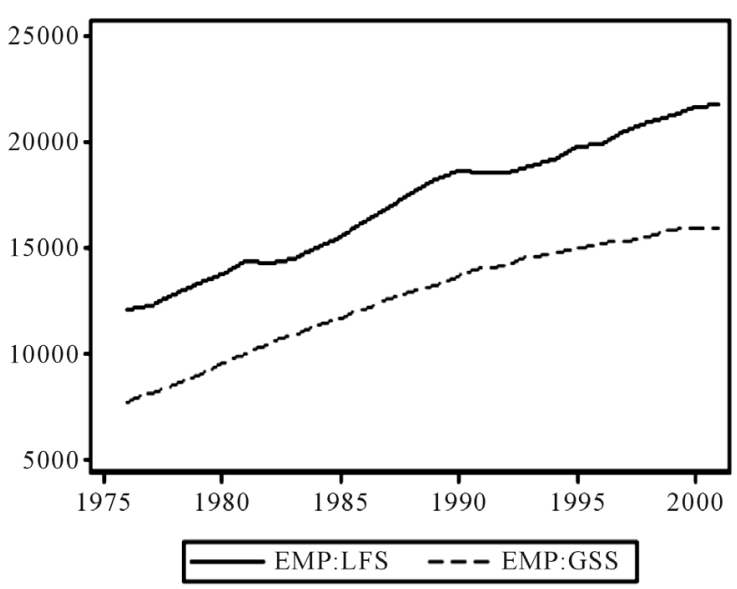

(a)

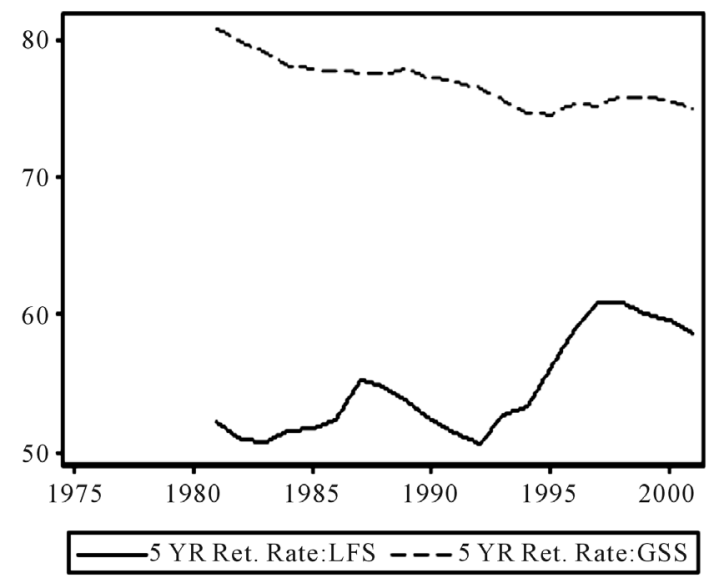

(c)

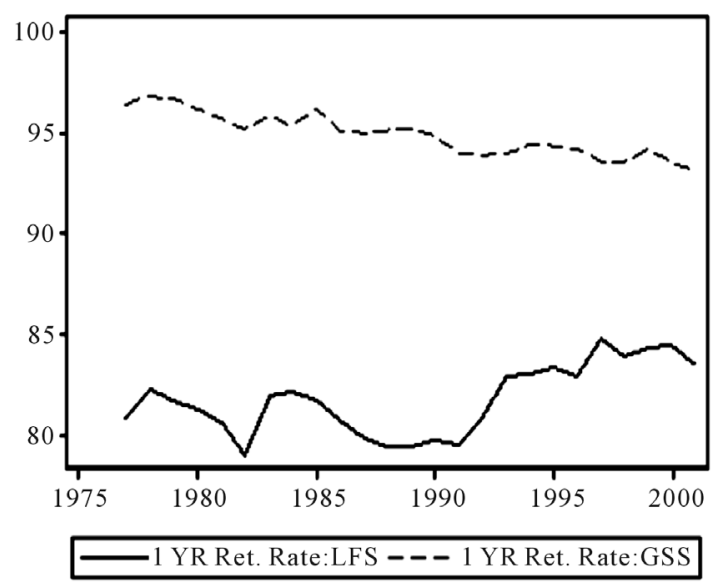

(b)

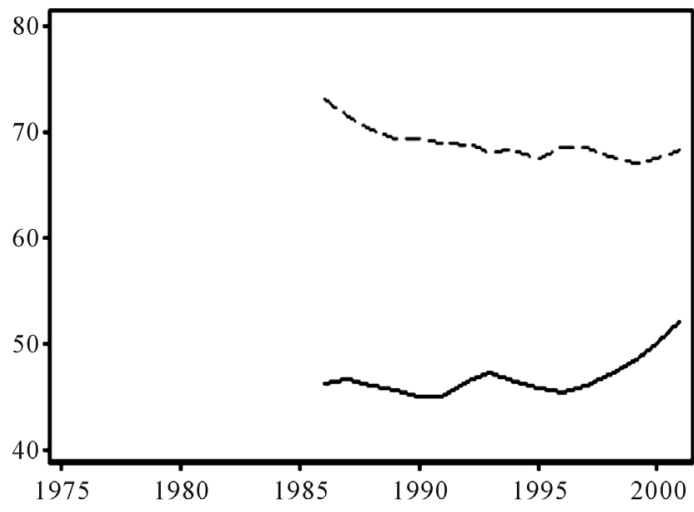

-10 YR Ret. Rate:LFS-- -10 YR Ret. Rate:GSS

(d)

Source: Labour force survey and general social survey (cycles 15 and 20).

Figure 1. Employment and retention rates.

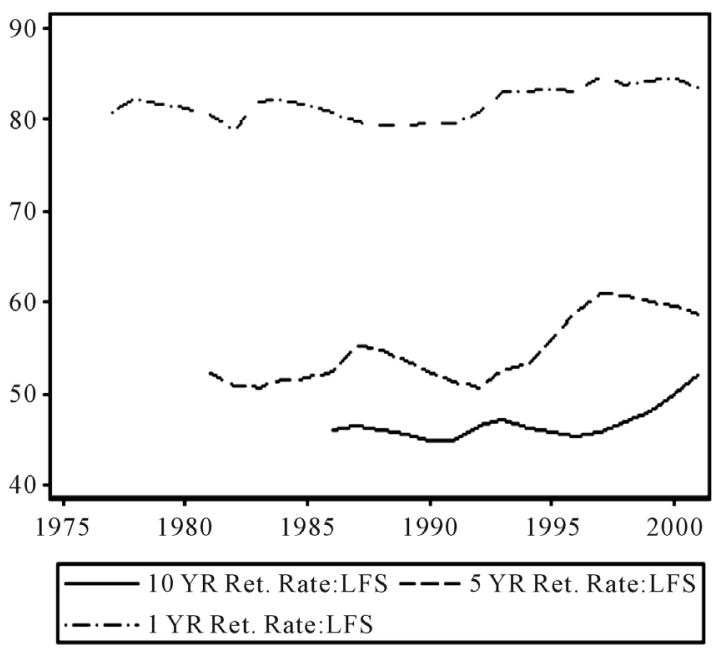

(a)

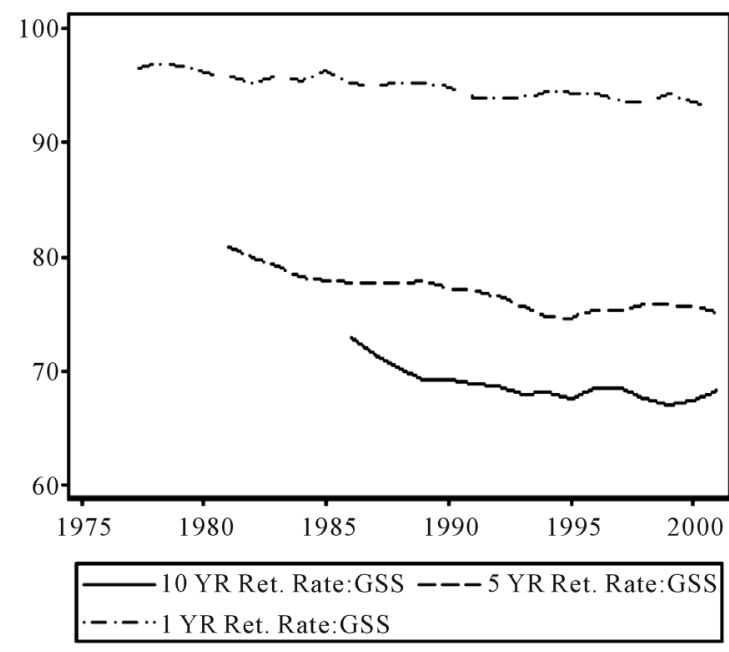

(b)

Source: Labour force survey and general social survey (cycles 15 and 20).

Figure 2. Comparative retention rates. 
Pairwise correlation coefficients between the GSS-based and LFS-based variables are presented in Table 2. Unsurprisingly, there is strong positive correlation between employment and attrition in both datasets due to thetime trend in employment and attrition levels. The correlation in retention rates, however, present more of a challenge as all correlations appear to be negative (and insignificant in the case of ten years retention rates).

To test whether there is an underlying correspondence between the series that may be masked by time trends an OLS population regression is run for each corresponding retention rate. The results are presented in Table 3. The results show that once the converging trends are controlled for, there is a significant and positive relationship between retention rates for the two series. The convergence of the two series can have different implications. One interpretation can be that work interruptions have become more common over time while job tenures have remained constant or increased on average. An alternate interpretation could be that either an inverse attrition bias in the GSS data or some form of recall errors have generated an artificial decline in retention rates over time. However, there data issues were examined in Ignaczak and Voia [13] with the conclusion that recall errors and attrition bias were unlikely to have caused serious deficiencies in the data. Hence, it is likely that institutional factors and more flexible labour market arrangements, such as increasingly generous unemployment insurance and parental provisions, have increased work separations while not necessarily decreasing job spell lengths.

\section{Empirical Methodology}

A Cox semiparametric hazard model which accounts for right-censoring is used to estimate the duration of the

Table 2. LFS and GSS variables correlation.

\begin{tabular}{ccc}
\hline & $\rho$ & $\mathrm{p}$-value \\
\hline Employment & 0.9899 & 0.0000 \\
1 yr attrition & 0.7713 & 0.0000 \\
5 yr attrition & 0.8475 & 0.0000 \\
10 yr attrition & 0.9615 & 0.0000 \\
1 yr ret rate & -0.4435 & 0.0298 \\
5 yr ret rate & -0.6277 & 0.0023 \\
10 yr ret rate & -0.3162 & 0.2327
\end{tabular}

Table 3. Population regression: GSS and LFS variables.

\begin{tabular}{cccc}
\hline & RR1 GSS & RR5 GSS & RR10 GSS \\
\hline RR1 LFS & $0.112^{* *}$ & & \\
RR5 LFS & $(0.052)$ & $0.136^{*}$ & \\
& & $(0.074)$ & $0.313^{* * *}$ \\
RR10 LFS & & $(0.14)$ \\
Trend & $-0.152^{* * *}$ & & $-0.354^{* * *}$ \\
Constant & $(0.012)$ & $-0.317^{* * *}$ & $(0.057)$ \\
T & $387.4^{* * *}$ & $(0.043)$ & $760.2^{* * *}$ \\
R & $(22.2)$ & $700.1^{* * *}$ & $(108.9)$ \\
p(D) & 25 & $(83.1)$ & 16 \\
\hline
\end{tabular}

Notes: Standard errors are in parentheses. ${ }^{*},{ }^{* *}$, and ${ }^{* * *}$ denote 1\%, 5\%, and 10\% level of significance, respectively. p(D) represents the p-value of Durbin's alternative test for autocorrelation where no autocorrelation is assumed under the null. 
first employment spell. Only spells with a specified starting date are considered eliminating any left-censoring problems. The following econometric model is considered:

$$
\theta\left(t_{i} \mid x_{i}\right)=\phi\left(x_{i}\right) \lambda\left(t_{i}\right)
$$

where $\theta(\cdot)$ is the hazard rate, $t_{i}$ is the duration of the first employment spell for individual $i, \phi\left(x_{i}\right)=\exp \left(x_{i} \beta\right)$ and $\lambda\left(t_{i}\right)$ is the baseline hazard for individual $i$. The Cox model is a good choice because it is robust to misspecification due to its flexible (nonparametric) baseline hazard.

In order to focus on the specific topic of institutional changes over the period under study a series of competing risks regressions will also be estimated. The competing risks regressions follow the method of Fine and Grey [16] which produces parameter estimates that contribute to the sub-hazard of separation for a particular risk factor rather than the overall hazard of separation. The sub-hazards of interest are separations due to work-related reasons for men and maternity/parental separation for women. These gender-specific subhazards are targeted solely because of the nature of the hazards by gender. The high hazard for women early in the spell relative to men is most likely caused by family formation. For men that stability literature has focused on structural changes in the market for labour, with a focus on dislocation. The competing risks in both cases will be any reason with the exception of those identified above. All unfinished spells are right censored and no left censoring exists in the dataset. The econometric model describing a competing risks regression is similar to the Cox proportional hazards model and takes the form:

$$
\theta_{1}\left(t_{i} \mid x_{i}\right)=\phi\left(x_{i}\right) \lambda_{1,0}\left(t_{i}\right)
$$

where $\theta_{1}(\cdot)$ is the subhazard rate, $t_{i}$ is the duration of the first employment spell for individual $i$, $\phi\left(x_{i}\right)=\exp \left(x_{i} \beta\right)$ and $\lambda_{1,0}\left(t_{i}\right)$ is the baseline subhazard for individual $i$.

\section{Results}

Before moving on to the model results it is worthwhile to examine the empirical hazard functions graphically. Figure 3 presents the smoothed hazard functions of employment duration by gender and cohort at 15- and 45year intervals. The first thing to note in panels (a) and (b) is that the hazard rate is generally higher for women than for men. Secondly, when looking over a longer time horizon, in panels (c) and (d), one generally observes a

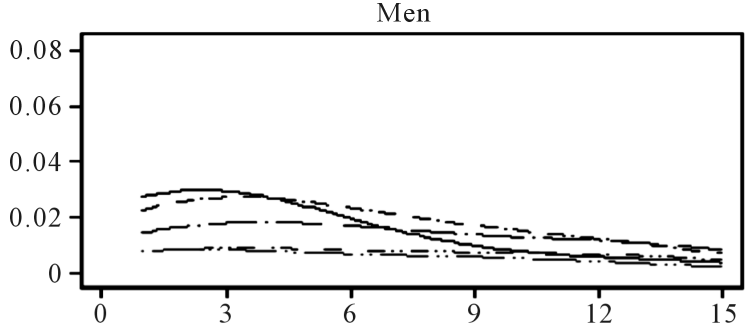

(a)

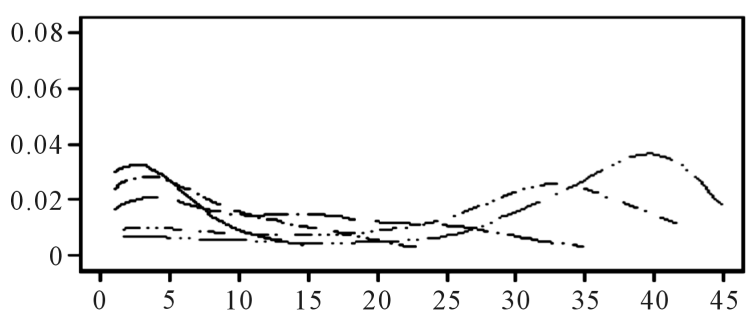

(c)

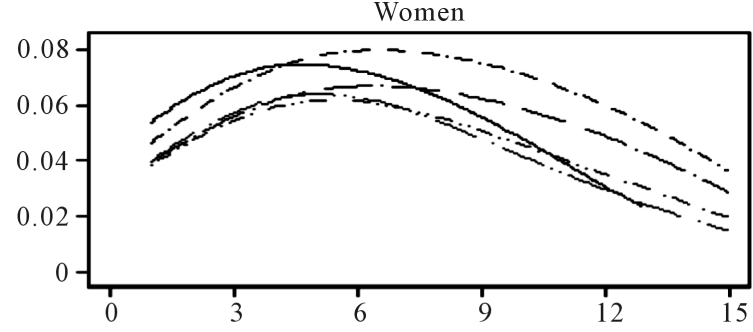

(b)

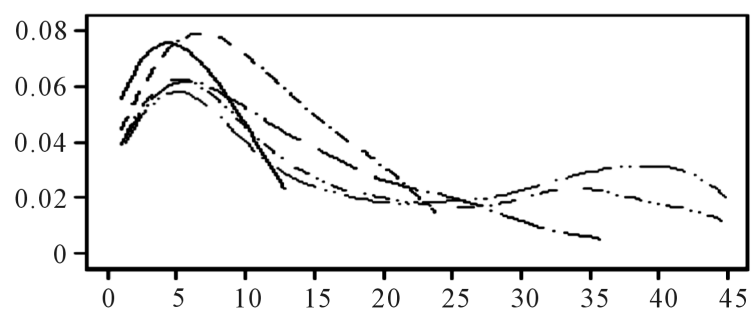

\begin{tabular}{|c|c|c|c|}
\hline$-\ldots-\cdots-$ & $\begin{array}{l}1970-79 \\
1940-49\end{array}$ & 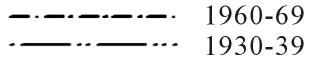 & $-\cdot-1950-59$ \\
\hline
\end{tabular}

(d)

Data source: General social survey cycles 15 and 20 (2001, 2006).

Note: The smoothed hazards above are displayed by birth cohort. Panels (a) and (c) are for men over a period of 15 and of 50 years respectively. Similarly, panels (b) and (d) are for women showing a 15- and 50-year period respectively. 
bimodal distribution, with higher hazards at the beginning and the end of the employment duration distribution. The likely reason for high initial hazards is low match quality between employers and employees in first employment spells while the rising hazard towards the end of the distribution signals movements into retirement. A general decrease in the hazard can be observed in panel (a) for succeeding cohorts of men, but the 1970s distribution tends to break from this pattern. While the employment hazards are more complicated for women it can also be recognized that the 1970s cohort also displays a higher hazard towards the beginning of the spell.

\subsection{Proportional Hazard Model Results}

The initial Cox proportional hazards model is estimated twelve times. Two full-sample estimates are made, one for men and the other for women, which include cohort-specific information as dummy variables. The ten other estimated equations consist of 5 cohort-specific equations for both genders. These results can be seen in Table 4

Table 4. Cox semiparametric estimates of employment spells: Men.

\begin{tabular}{|c|c|c|c|c|c|c|}
\hline & Total sample & C 1930-1939 & C 1940-1949 & C 1950-1959 & C 1960-1969 & C $1970-1979$ \\
\hline Part-time & $\begin{array}{l}1.372^{* * *} \\
(0.119)\end{array}$ & $\begin{array}{c}0.885 \\
(0.549)\end{array}$ & $\begin{array}{l}1.073^{* * * *} \\
(0.357)\end{array}$ & $\begin{array}{l}1.647^{* * *} \\
(0.271)\end{array}$ & $\begin{array}{l}1.568^{* * *} \\
(0.294)\end{array}$ & $\begin{array}{l}1.427^{* * * *} \\
(0.172)\end{array}$ \\
\hline Immigrant & $\begin{array}{c}-0.117^{* *} \\
(0.053)\end{array}$ & $\begin{array}{c}-0.266^{*} \\
(0.161)\end{array}$ & $\begin{array}{c}-0.193 \\
(0.13)\end{array}$ & $\begin{array}{c}-0.273^{* *} \\
(0.109)\end{array}$ & $\begin{array}{c}0.099 \\
(0.1)\end{array}$ & $\begin{array}{c}-0.053 \\
(0.12)\end{array}$ \\
\hline Married & $\begin{array}{l}-0.141^{*} \\
(0.078)\end{array}$ & $\begin{array}{l}-0.165 \\
(0.235)\end{array}$ & $\begin{array}{l}-0.077 \\
(0.157)\end{array}$ & $\begin{array}{c}-0.2 \\
(0.145)\end{array}$ & $\begin{array}{l}-0.091 \\
(0.158)\end{array}$ & $\begin{array}{l}-0.416^{*} \\
(0.218)\end{array}$ \\
\hline Age began & $\begin{array}{l}0.053^{* * * *} \\
(0.006)\end{array}$ & $\begin{array}{l}0.054^{* * * *} \\
(0.017)\end{array}$ & $\begin{array}{l}0.058^{* * * *} \\
(0.011)\end{array}$ & $\begin{array}{l}0.042^{* * * *} \\
(0.012)\end{array}$ & $\begin{array}{l}0.065^{* * * *} \\
(0.015)\end{array}$ & $\begin{array}{c}0.062^{* * *} \\
(0.02)\end{array}$ \\
\hline Parental & $\begin{array}{l}1.724^{* * *} \\
(0.084)\end{array}$ & & & $\begin{array}{l}1.983^{* * * *} \\
(0.232)\end{array}$ & $\begin{array}{l}1.803^{* * * *} \\
(0.118)\end{array}$ & $\begin{array}{l}1.656^{* * *} \\
(0.159)\end{array}$ \\
\hline Work related & $\begin{array}{l}1.846^{* * * *} \\
(0.044)\end{array}$ & $\begin{array}{l}1.646^{* * *} \\
(0.205)\end{array}$ & $\begin{array}{l}1.723^{* * *} \\
(0.119)\end{array}$ & $\begin{array}{l}1.956^{* * *} \\
(0.091)\end{array}$ & $\begin{array}{l}1.899^{* * *} \\
(0.086)\end{array}$ & $\begin{array}{l}1.958^{* * *} \\
(0.089)\end{array}$ \\
\hline UR gap & $\begin{array}{l}0.218^{* * * *} \\
(0.041)\end{array}$ & $\begin{array}{l}0.373^{* * * *} \\
(0.127)\end{array}$ & $\begin{array}{c}0.117 \\
(0.107)\end{array}$ & $\begin{array}{l}0.321^{* * * *} \\
(0.078)\end{array}$ & $\begin{array}{l}0.175^{* *} \\
(0.081)\end{array}$ & $\begin{array}{l}0.247^{* *} \\
(0.097)\end{array}$ \\
\hline High school & $\begin{array}{c}-0.02 \\
(0.089)\end{array}$ & $\begin{array}{c}0.062 \\
(0.217)\end{array}$ & $\begin{array}{l}-0.292 \\
(0.181)\end{array}$ & $\begin{array}{c}-0.387^{* *} \\
(0.159)\end{array}$ & $\begin{array}{l}-0.061 \\
(0.202)\end{array}$ & $\begin{array}{c}0.261 \\
(0.253)\end{array}$ \\
\hline College & $\begin{array}{c}-0.015 \\
(0.09)\end{array}$ & $\begin{array}{c}0.37 \\
(0.233)\end{array}$ & $\begin{array}{l}-0.104 \\
(0.177)\end{array}$ & $\begin{array}{l}-0.32^{*} \\
(0.166)\end{array}$ & $\begin{array}{l}-0.116 \\
(0.199)\end{array}$ & $\begin{array}{c}0.154 \\
(0.253)\end{array}$ \\
\hline University & $\begin{array}{l}-0.19^{* * *} \\
(0.089)\end{array}$ & $\begin{array}{c}0.321 \\
(0.215)\end{array}$ & $\begin{array}{c}-0.446^{* *} \\
(0.179)\end{array}$ & $\begin{array}{c}-0.549^{* * * *} \\
(0.16)\end{array}$ & $\begin{array}{l}-0.154 \\
(0.197)\end{array}$ & $\begin{array}{l}-0.123 \\
(0.251)\end{array}$ \\
\hline С 1930-1939 & $\begin{array}{c}-2.455^{* * *} \\
(0.148)\end{array}$ & & & & & \\
\hline С 1940-1949 & $\begin{array}{c}-2.066^{* * *} \\
(0.121)\end{array}$ & & & & & \\
\hline С 1950-1959 & $\begin{array}{c}-1.586^{* * *} \\
(0.11)\end{array}$ & & & & & \\
\hline С 1960-1969 & $\begin{array}{c}-1.111^{* * *} \\
(0.103)\end{array}$ & & & & & \\
\hline C 1970-1979 & $\begin{array}{l}-0.5^{* * *} \\
(0.098)\end{array}$ & & & & & \\
\hline Observations & 7196 & 531 & 1028 & 1495 & 1944 & 1673 \\
\hline log likelihood & $-21,244$ & -1597 & -2924 & -3840 & -4919 & -3566 \\
\hline
\end{tabular}

Notes: Standard errors are in parentheses. ${ }^{*},{ }^{* *}$, and ${ }^{* * *}$ denote $1 \%, 5 \%$, and $10 \%$ level of significance, respectively. C $1930-1939$ refers to the 1930-1939 birth cohort, similarly, the C 1940-1949 to C 1970-1979 refer to the birth cohort 1940-1949 to 1970-1979. 
and Table 5. The results imply that part-time work, the age at which the spell began, parental or work-related separations as well as adverse macroeconomic circumstances (proxied by the unemployment rate gap) raise the hazard for men. Reductions in the hazard for men are caused by being an immigrant or married at the start of the spell. The rising cohort effect seen in the aggregate equation for men shows that more recent cohorts of men have a higher hazard of leaving employment. In the cohort-specific equation the increase in work related separation for the 1950s cohort and onward seems to coincide with a reduced macro cyclical effect after the 1950s

Table 5. Cox semiparametric estimates of employment spells: Women.

\begin{tabular}{|c|c|c|c|c|c|c|}
\hline & Total sample & C 1930-1939 & C 1940-1949 & C 1950-1959 & C 1960-1969 & C $1970-1979$ \\
\hline Part-time & $\begin{array}{l}0.662^{* * *} \\
(0.052)\end{array}$ & $\begin{array}{l}0.252^{*} \\
(0.152)\end{array}$ & $\begin{array}{l}0.393^{* * *} \\
(0.134)\end{array}$ & $\begin{array}{l}0.518^{* * *} \\
(0.128)\end{array}$ & $\begin{array}{l}0.766^{* * *} \\
(0.115)\end{array}$ & $\begin{array}{l}0.828^{* * * *} \\
(0.097)\end{array}$ \\
\hline Immigrant & $\begin{array}{c}-0.126^{* * *} \\
(0.033)\end{array}$ & $\begin{array}{c}-0.173^{* * *} \\
(0.087)\end{array}$ & $\begin{array}{c}-0.202^{* *} \\
(0.082)\end{array}$ & $\begin{array}{c}-0.257^{* * *} \\
(0.07)\end{array}$ & $\begin{array}{l}-0.102 \\
(0.067)\end{array}$ & $\begin{array}{l}-0.055 \\
(0.072)\end{array}$ \\
\hline Married & $\begin{array}{l}-0.003 \\
(0.045)\end{array}$ & $\begin{array}{l}-0.199 \\
(0.126)\end{array}$ & $\begin{array}{l}-0.19^{*} \\
(0.103)\end{array}$ & $\begin{array}{l}0.008 \\
(0.09)\end{array}$ & $\begin{array}{l}0.099 \\
(0.09)\end{array}$ & $\begin{array}{l}0.263^{* * * *} \\
(0.099)\end{array}$ \\
\hline Age began & $\begin{array}{l}0.007^{* *} \\
(0.003)\end{array}$ & $\begin{array}{l}0.015^{* *} \\
(0.007)\end{array}$ & $\begin{array}{l}0.015^{* *} \\
(0.006)\end{array}$ & $\begin{array}{c}0.002 \\
(0.007)\end{array}$ & $\begin{array}{l}0.031^{* * * *} \\
(0.008)\end{array}$ & $\begin{array}{l}0.06^{* * *} \\
(0.011)\end{array}$ \\
\hline Parental & $\begin{array}{c}1.206^{* * *} \\
(0.03)\end{array}$ & $\begin{array}{l}1.377^{* * *} \\
(0.112)\end{array}$ & $\begin{array}{l}1.328^{* * *} \\
(0.086)\end{array}$ & $\begin{array}{l}1.346^{* * *} \\
(0.067)\end{array}$ & $\begin{array}{l}1.252^{* * *} \\
(0.059)\end{array}$ & $\begin{array}{l}1.162^{* * * *} \\
(0.061)\end{array}$ \\
\hline Work related & $\begin{array}{l}1.04^{* * *} \\
(0.046)\end{array}$ & $\begin{array}{l}0.826^{* * *} \\
(0.134)\end{array}$ & $\begin{array}{l}0.91^{* * *} \\
(0.095)\end{array}$ & $\begin{array}{l}0.967^{* * *} \\
(0.089)\end{array}$ & $\begin{array}{l}1.028^{* * *} \\
(0.091)\end{array}$ & $\begin{array}{l}1.318^{* * *} \\
(0.113)\end{array}$ \\
\hline UR gap & $\begin{array}{l}0.066^{* * *} \\
(0.014)\end{array}$ & $\begin{array}{l}0.081^{* *} \\
(0.041)\end{array}$ & $\begin{array}{l}0.071^{*} \\
(0.043)\end{array}$ & $\begin{array}{c}0.034 \\
(0.022)\end{array}$ & $\begin{array}{c}0.093^{* * *} \\
(0.03)\end{array}$ & $\begin{array}{c}0.208^{* * *} \\
(0.05)\end{array}$ \\
\hline High school & $\begin{array}{l}0.102^{*} \\
(0.058)\end{array}$ & $\begin{array}{c}0.007 \\
(0.117)\end{array}$ & $\begin{array}{c}0.056 \\
(0.105)\end{array}$ & $\begin{array}{c}-0.024 \\
(0.12)\end{array}$ & $\begin{array}{c}0.119 \\
(0.145)\end{array}$ & $\begin{array}{l}-0.085 \\
(0.233)\end{array}$ \\
\hline College & $\begin{array}{l}0.137^{* *} \\
(0.058)\end{array}$ & $\begin{array}{c}0.098 \\
(0.119)\end{array}$ & $\begin{array}{c}0.074 \\
(0.108)\end{array}$ & $\begin{array}{c}0.049 \\
(0.121)\end{array}$ & $\begin{array}{c}0.188 \\
(0.144)\end{array}$ & $\begin{array}{l}-0.055 \\
(0.232)\end{array}$ \\
\hline University & $\begin{array}{l}0.122^{* *} \\
(0.059)\end{array}$ & $\begin{array}{c}0.111 \\
(0.144)\end{array}$ & $\begin{array}{c}0.003 \\
(0.117)\end{array}$ & $\begin{array}{c}0.128 \\
(0.125)\end{array}$ & $\begin{array}{c}0.08 \\
(0.146)\end{array}$ & $\begin{array}{l}-0.153 \\
(0.227)\end{array}$ \\
\hline C 1930-1939 & $\begin{array}{c}-1.334^{* * *} \\
(0.086)\end{array}$ & & & & & \\
\hline C 1940-1949 & $\begin{array}{c}-1.286^{* * *} \\
(0.078)\end{array}$ & & & & & \\
\hline C 1950-1959 & $\begin{array}{c}-1.174^{* * *} \\
(0.073)\end{array}$ & & & & & \\
\hline С $1960-1969$ & $\begin{array}{c}-0.997^{* * *} \\
(0.071)\end{array}$ & & & & & \\
\hline С 1970-1979 & $\begin{array}{l}-0.62^{* * *} \\
(0.072)\end{array}$ & & & & & \\
\hline Observations & 9957 & 952 & 1478 & 2118 & 2540 & 2222 \\
\hline log likelihood & $-57,739$ & -4651 & -7399 & $-10,897$ & $-13,327$ & -9392 \\
\hline
\end{tabular}

Notes: Standard errors are in parentheses. ${ }^{*},{ }^{* *}$, and ${ }^{* * *}$ denote $1 \%, 5 \%$, and $10 \%$ level of significance, respectively. C $1930-1939$ refers to the 1930-1939 birth cohort, similarly, the C 1940-1949 to C 1970-1979 refer to the birth cohort 1940-1949 to 1970-1979. 
cohort. Furthermore, higher levels of education no longer decrease men's hazard after the 1950s cohort. For women, the aggregate hazard rises with part-time employment, the age work began, parental and work related separations, and macro conditions. Education tends to increase the hazard, but only in the aggregate. Being an immigrant or a worker from an earlier cohort also reduces the hazard. When examining the cohort specific equations for women a clear upward trend can be seen in the contribution of part-time employment to the hazard. The effects from parental leave declined after the 1950s cohort while those of macroeconomic conditions and work related separations increased their effects on the hazard.

When performing any form of hazard analysis it is important to examine the baseline hazard in order to determine whether duration dependence is present in the model. Zorn [17] describes duration dependence as the extent to which the baseline hazard is increasing or decreasing. When unobserved heterogeneity is present, spurious duration dependence can present a problem as high hazard individuals leave the sample faster than low hazard individuals. This process will leave a characteristic decline in the baseline hazard. However, true duration dependence (state dependence) can also be present in the model causing the baseline hazard to rise or fall as duration in the state affects the probability of a separation event being realized.

The full sample baseline hazard is shown in Figure 4. It can be clearly seen that the baseline hazard decreases over the first 20 years and then rapidly increases, thus displaying negative duration dependence over the first 20 years and positive duration dependence thereafter. This pattern is not necessarily a problem as it is, at least in part, due to state dependence regarding the quality of employment matches for shorter spells and issues around retirement in the longer spells. Censoring issues in the last 30 years of the chart may also be affecting the baseline. The estimation is carried out by cohort since the censoring is directly related to the time when workers enter employment. Modeling the gender difference using a Gamma shared frailty term was attempted but led to insignificant results, hence the estimates are also disaggregated by gender.

To check for spurious duration dependence in the disaggregated equations the baseline hazards are examined by gender and cohort in Figure 5 and Figure 6. With the exception of the first few years, most of the cohortspecific hazards of men do not show any duration dependence (the upward trends at the ends of the baseline hazards for men of the 1960s and 1970s cohort share likely due to censoring issues). In the case of women, the 1930s and 1940s cohorts display rising duration dependence for the first $6-7$ years and falling duration dependence for the subsequent 5 - 8 years. This pattern may be an artifact of the expectation that women of the era were expected to work for a few years before leaving the labour force to raise a family, hence this form of duration dependence is unlikely to be spurious.

To determine the adequacy of the equation specifications an examination of the Schoenfeld Residuals was performed for each covariate in the equations. Table 6 contains the p-values for both the global and variable-specific tests of proportionality. The results clearly indicate that many of the covariates fail the proportionality assumption, implying that their effects on the baseline hazard vary with time.

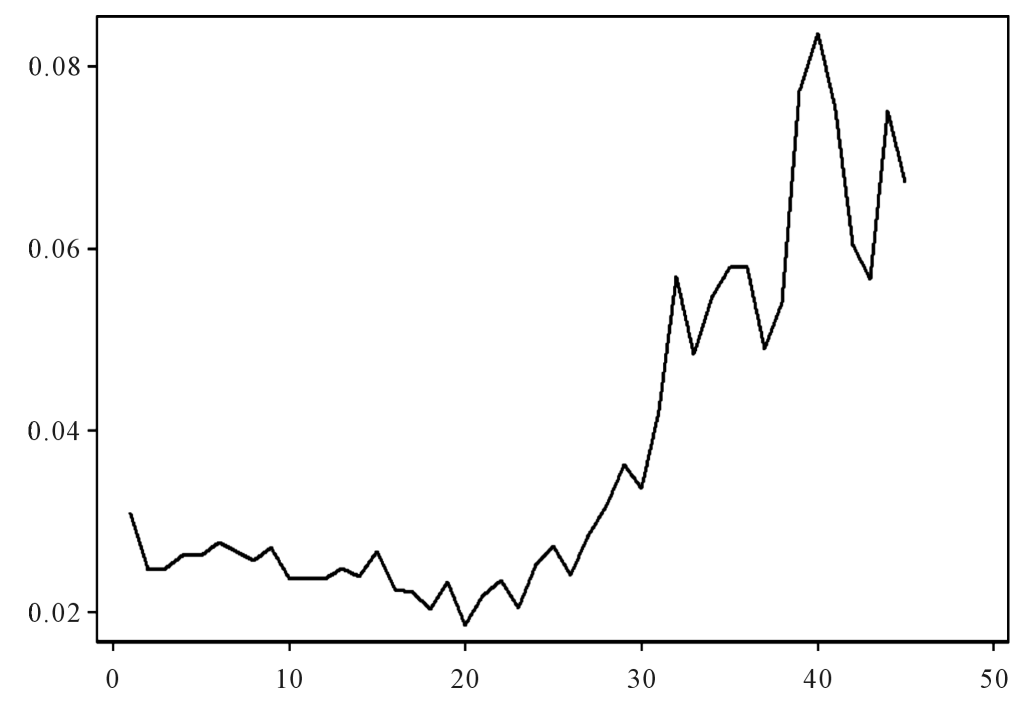

Figure 4. Total baseline hazard. 


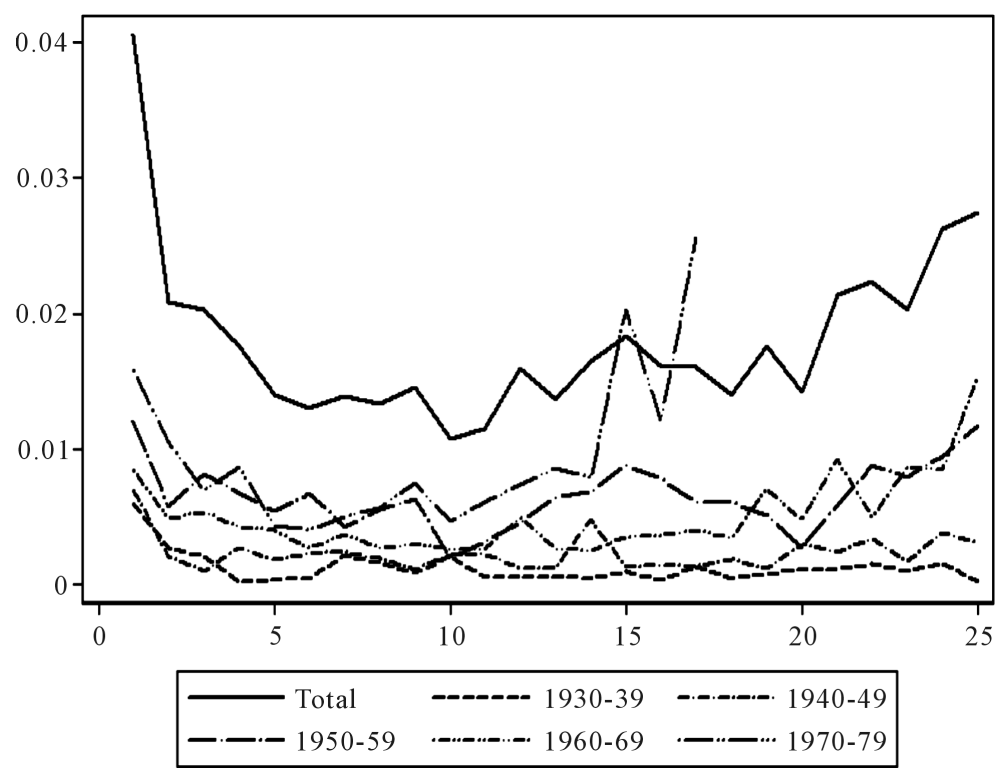

Data source: General social survey cycles 15 and 20 (2001, 2006).

Figure 5. Baseline hazard plots by cohort: Men.

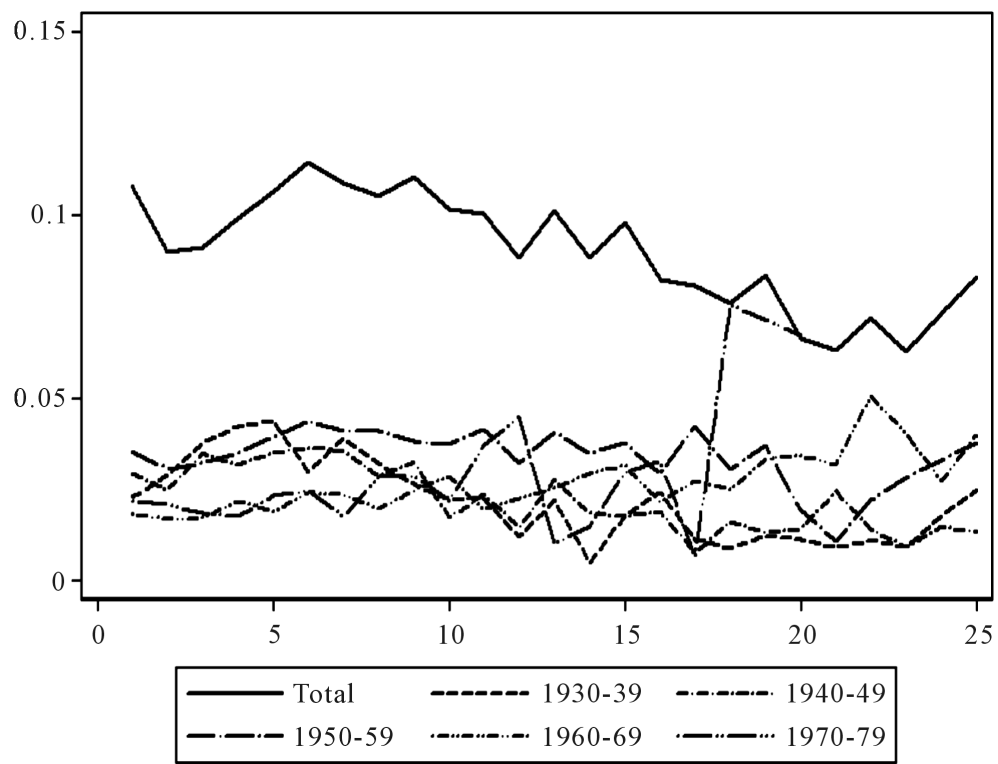

Data source: General social survey cycles 15 and 20 (2001, 2006).

Figure 6. Baseline hazard plots by cohort: Women.

Time dependence is introduced into the models due to a general failure of proportionality in most of the subsamples. These results should not be entirely surprising due to the length of time under observation, particularly in the full sample and earlier cohorts. Work-related separations and the unemployment rate gap are modeled as time-varying covariates for men. For women, separations for parental reasons are modeled as time-varying. While there were numerous proportionality failures in individual estimation, these variables were specifically chosen due to the consistency in failure across cohorts. Moreover, because of the difficulty in interpreting timevarying covariates [18] standardization of the time varying covariates was important for cross-cohort comparisons.

To examine the hypothesis of decreasing employment tenure, the focus is on employment durations by birth cohort. The results of the estimation, seen in Table 7 and Table 8, show the hazard results for men and women 
Table 6. Probability values for the schoenfeld residual test of proportionality.

\begin{tabular}{|c|c|c|c|c|c|c|}
\hline & Total sample & C 1930-1939 & С $1940-1949$ & С 1950-1959 & С $1960-1969$ & C 1970-1979 \\
\hline \multicolumn{7}{|c|}{ Men } \\
\hline Part-time & 0.0007 & 0.058 & 0.0007 & 0.9401 & 0 & 0.3717 \\
\hline Immigrant & 0.0249 & 0.0523 & 0.2067 & 0.2632 & 0.7602 & 0.0133 \\
\hline Married & 0.2952 & 0.2495 & 0.5267 & 0.1122 & 0.9331 & 0.8851 \\
\hline Age began & 0 & 0.6897 & 0 & 0.3128 & 0 & 0.481 \\
\hline Parental & 0.6519 & - & - & 0.9609 & 0.23 & 0.0435 \\
\hline Work rel. & 0.001 & 0.6897 & 0.0181 & 0.5235 & 0.6401 & 0.0026 \\
\hline UR gap & 0 & 0.0004 & 0 & 0 & 0 & 0.7901 \\
\hline High sch. & 0.9331 & 0.0307 & 0.4025 & 0.2251 & 0.0647 & 0.9222 \\
\hline College & 0.1784 & 0.6905 & 0.0339 & 0.2706 & 0.0443 & 0.8352 \\
\hline Univ. & 0.03 & 0.137 & 0.0105 & 0.4853 & 0.0973 & 0.8203 \\
\hline Global test & 0 & 0.0023 & 0 & 0 & 0 & 0.058 \\
\hline $\mathrm{N}$ & 7196 & 531 & 1028 & 1495 & 1944 & 1673 \\
\hline \multicolumn{7}{|c|}{ Women } \\
\hline Part-time & 0 & 0.5041 & 0.0821 & 0.0428 & 0.0768 & 0.0776 \\
\hline Immigrant & 0.2099 & 0.4283 & 0.9572 & 0.6719 & 0.5309 & 0.0263 \\
\hline Married & 0.4289 & 0.0038 & 0.7672 & 0.6584 & 0.2385 & 0.984 \\
\hline Age began & 0 & 0.1249 & 0.0002 & 0 & 0.0263 & 0.495 \\
\hline Parental & 0 & 0.0022 & 0.0006 & 0 & 0 & 0 \\
\hline Work rel. & 0.0427 & 0.7482 & 0.1059 & 0 & 0.9597 & 0.2519 \\
\hline UR gap & 0.0039 & 0.246 & 0 & 0.064 & 0.1002 & 0.3607 \\
\hline High sch. & 0.0739 & 0.7979 & 0.3908 & 0.9054 & 0.3423 & 0.0001 \\
\hline College & 0.0046 & 0.939 & 0.001 & 0.3942 & 0.6602 & 0.0005 \\
\hline Univ. & 0.0013 & 0.5893 & 0.0724 & 0.4693 & 0.5767 & 0.0001 \\
\hline Global test & 0 & 0.0006 & 0 & 0 & 0 & 0 \\
\hline $\mathrm{N}$ & 9957 & 952 & 1478 & 2118 & 2540 & 2222 \\
\hline
\end{tabular}

Notes: Standard errors are in parentheses. ${ }^{*},{ }^{* *}$, and ${ }^{* * *}$ denote $1 \%, 5 \%$, and $10 \%$ level of significance, respectively. C $1930-1939$ refers to the 1930-1939 birth cohort, similarly, the C 1940-1949 to C 1970-1979 refer to the birth cohort 1940-1949 to 1970-1979. 
Table 7. Cox semiparametric estimates of employment spells with time-varying covariates: Men.

\begin{tabular}{|c|c|c|c|c|c|c|}
\hline & Total sample & C 1930-1939 & C 1940-1949 & C 1950-1959 & C 1960-1969 & C $1970-1979$ \\
\hline \multicolumn{7}{|c|}{ Time-invariant } \\
\hline Part-time & $\begin{array}{l}1.239^{* * *} \\
(0.101)\end{array}$ & $\begin{array}{c}0.735 \\
(0.535)\end{array}$ & $\begin{array}{l}0.829^{* *} \\
(0.334)\end{array}$ & $\begin{array}{l}1.204^{* * *} \\
(0.273)\end{array}$ & $\begin{array}{l}1.486^{* * *} \\
(0.239)\end{array}$ & $\begin{array}{l}1.414^{* * * *} \\
(0.156)\end{array}$ \\
\hline Immigrant & $\begin{array}{c}-0.143^{* * * *} \\
(0.054)\end{array}$ & $\begin{array}{l}-0.207 \\
(0.165)\end{array}$ & $\begin{array}{c}-0.221^{*} \\
(0.129)\end{array}$ & $\begin{array}{c}-0.299^{* * *} \\
(0.105)\end{array}$ & $\begin{array}{c}0.09 \\
(0.099)\end{array}$ & $\begin{array}{c}0.03 \\
(0.124)\end{array}$ \\
\hline Married & $\begin{array}{c}-0.187^{* *} \\
(0.08)\end{array}$ & $\begin{array}{l}-0.172 \\
(0.246)\end{array}$ & $\begin{array}{l}-0.183 \\
(0.157)\end{array}$ & $\begin{array}{c}-0.348^{* *} \\
(0.144)\end{array}$ & $\begin{array}{l}-0.125 \\
(0.165)\end{array}$ & $\begin{array}{c}-0.474^{*} \\
(0.244)\end{array}$ \\
\hline Age began & $\begin{array}{l}0.05^{* * * *} \\
(0.006)\end{array}$ & $\begin{array}{l}0.052^{* * *} \\
(0.018)\end{array}$ & $\begin{array}{l}0.065^{* * *} \\
(0.012)\end{array}$ & $\begin{array}{l}0.045^{* * * *} \\
(0.012)\end{array}$ & $\begin{array}{l}0.06^{* * * *} \\
(0.013)\end{array}$ & $\begin{array}{c}0.062^{* * * *} \\
(0.02)\end{array}$ \\
\hline Parental & $\begin{array}{l}1.34^{* * * *} \\
(0.079)\end{array}$ & & & $\begin{array}{l}1.564^{* * *} \\
(0.215)\end{array}$ & $\begin{array}{l}1.4^{* * * *} \\
(0.111)\end{array}$ & $\begin{array}{l}1.398^{* * *} \\
(0.138)\end{array}$ \\
\hline High school & $\begin{array}{l}-0.116 \\
(0.091)\end{array}$ & $\begin{array}{l}-0.102 \\
(0.22)\end{array}$ & $\begin{array}{c}-0.333^{*} \\
(0.172)\end{array}$ & $\begin{array}{c}-0.572^{* * * *} \\
(0.155)\end{array}$ & $\begin{array}{c}-0.394^{* *} \\
(0.191)\end{array}$ & $\begin{array}{c}0.187 \\
(0.276)\end{array}$ \\
\hline College & $\begin{array}{l}-0.101 \\
(0.091)\end{array}$ & $\begin{array}{c}0.185 \\
(0.244)\end{array}$ & $\begin{array}{l}-0.053 \\
(0.169)\end{array}$ & $\begin{array}{c}-0.444^{* * *} \\
(0.158)\end{array}$ & $\begin{array}{c}-0.405^{* *} \\
(0.189)\end{array}$ & $\begin{array}{c}0.124 \\
(0.276)\end{array}$ \\
\hline University & $\begin{array}{c}-0.316^{* * * *} \\
(0.09)\end{array}$ & $\begin{array}{c}0.155 \\
(0.213)\end{array}$ & $\begin{array}{c}-0.478^{* * *} \\
(0.175)\end{array}$ & $\begin{array}{c}-0.675^{* * *} \\
(0.153)\end{array}$ & $\begin{array}{c}-0.417^{* *} \\
(0.184)\end{array}$ & $\begin{array}{l}-0.175 \\
(0.276)\end{array}$ \\
\hline С 1930-1939 & $\begin{array}{c}-2.439^{* * * *} \\
(0.153)\end{array}$ & & & & & \\
\hline С 1940-1949 & $\begin{array}{c}-1.911^{* * *} \\
(0.125)\end{array}$ & & & & & \\
\hline C 1950-1959 & $\begin{array}{c}-1.322^{* * * *} \\
(0.114)\end{array}$ & & & & & \\
\hline С 1960-1969 & $\begin{array}{c}-0.825^{* * *} \\
(0.106)\end{array}$ & & & & & \\
\hline C 1970-1979 & $\begin{array}{c}-0.388^{* * *} \\
(0.105)\end{array}$ & & & & & \\
\hline \multicolumn{7}{|c|}{ Time-varying } \\
\hline Work related & $\begin{array}{l}0.037^{* * *} \\
(0.002)\end{array}$ & $\begin{array}{l}0.023^{* * * *} \\
(0.005)\end{array}$ & $\begin{array}{l}0.029^{* * * *} \\
(0.004)\end{array}$ & $\begin{array}{l}0.045^{* * *} \\
(0.003)\end{array}$ & $\begin{array}{l}0.057^{* * *} \\
(0.006)\end{array}$ & $\begin{array}{l}0.131^{* * *} \\
(0.017)\end{array}$ \\
\hline UR gap & $\begin{array}{l}0.016^{* * *} \\
(0.002)\end{array}$ & $\begin{array}{l}0.009^{* * *} \\
(0.003)\end{array}$ & $\begin{array}{l}0.012^{* * *} \\
(0.003)\end{array}$ & $\begin{array}{l}0.026^{* * *} \\
(0.003)\end{array}$ & $\begin{array}{l}0.033^{* * *} \\
(0.005)\end{array}$ & $\begin{array}{l}0.07^{* * *} \\
(0.008)\end{array}$ \\
\hline Observations & 7196 & 531 & 1028 & 1495 & 1944 & 1673 \\
\hline log likelihood & $-21,878$ & -1627 & -2983 & -3993 & -5109 & -3679 \\
\hline
\end{tabular}

Notes: Standard errors are in parentheses. ${ }^{*}, * *$, and ${ }^{* * *}$ denote $1 \%, 5 \%$, and $10 \%$ level of significance, respectively. C $1930-1939$ refers to the 1930-1939 birth cohort, similarly, the C 1940-1949 to C 1970-1979 refer to the birth cohort 1940-1949 to 1970-1979. 
Table 8. Cox semiparametric estimates of employment spells with time-varying covariates: Women.

\begin{tabular}{|c|c|c|c|c|c|c|}
\hline & Total sample & C 1930-1939 & C 1940-1949 & C 1950-1959 & C 1960-1969 & C $1970-1979$ \\
\hline \multicolumn{7}{|c|}{ Time-invariant } \\
\hline Part-time & $\begin{array}{l}0.6^{* * * *} \\
(0.05)\end{array}$ & $\begin{array}{c}0.227 \\
(0.145)\end{array}$ & $\begin{array}{l}0.316^{* *} \\
(0.129)\end{array}$ & $\begin{array}{l}0.506^{* * *} \\
(0.124)\end{array}$ & $\begin{array}{l}0.725^{* * *} \\
(0.107)\end{array}$ & $\begin{array}{l}0.766^{* * *} \\
(0.094)\end{array}$ \\
\hline Immigrant & $\begin{array}{c}-0.162^{* * *} \\
(0.035)\end{array}$ & $\begin{array}{c}-0.182^{*} \\
(0.093)\end{array}$ & $\begin{array}{c}-0.187^{* *} \\
(0.085)\end{array}$ & $\begin{array}{c}-0.274^{* * *} \\
(0.074)\end{array}$ & $\begin{array}{c}-0.147^{* *} \\
(0.07)\end{array}$ & $\begin{array}{l}-0.098 \\
(0.078)\end{array}$ \\
\hline Married & $\begin{array}{l}-0.056 \\
(0.047)\end{array}$ & $\begin{array}{c}-0.264^{* *} \\
(0.121)\end{array}$ & $\begin{array}{c}-0.255^{* *} \\
(0.101)\end{array}$ & $\begin{array}{l}-0.094 \\
(0.092)\end{array}$ & $\begin{array}{c}0.008 \\
(0.094)\end{array}$ & $\begin{array}{l}0.335^{* * *} \\
(0.108)\end{array}$ \\
\hline Age began & $\begin{array}{l}-0.004 \\
(0.003)\end{array}$ & $\begin{array}{c}0.006 \\
(0.006)\end{array}$ & $\begin{array}{c}0.002 \\
(0.006)\end{array}$ & $\begin{array}{c}-0.014^{* *} \\
(0.007)\end{array}$ & $\begin{array}{c}0.011 \\
(0.008)\end{array}$ & $\begin{array}{l}0.045^{* * *} \\
(0.012)\end{array}$ \\
\hline Work rel. & $\begin{array}{c}0.754^{* * *} \\
(0.04)\end{array}$ & $\begin{array}{l}0.645^{* * *} \\
(0.121)\end{array}$ & $\begin{array}{l}0.649^{* * *} \\
(0.088)\end{array}$ & $\begin{array}{l}0.653^{* * *} \\
(0.077)\end{array}$ & $\begin{array}{l}0.689^{* * * *} \\
(0.079)\end{array}$ & $\begin{array}{l}1.08^{* * *} \\
(0.094)\end{array}$ \\
\hline UR gap & $\begin{array}{l}0.085^{* * *} \\
(0.015)\end{array}$ & $\begin{array}{l}0.08^{* *} \\
(0.04)\end{array}$ & $\begin{array}{l}0.082^{* *} \\
(0.042)\end{array}$ & $\begin{array}{l}0.052^{* *} \\
(0.024)\end{array}$ & $\begin{array}{l}0.145^{* * *} \\
(0.033)\end{array}$ & $\begin{array}{l}0.19^{* * *} \\
(0.056)\end{array}$ \\
\hline High sch. & $\begin{array}{l}0.116^{* *} \\
(0.057)\end{array}$ & $\begin{array}{c}0.032 \\
(0.116)\end{array}$ & $\begin{array}{l}0.072 \\
(0.1)\end{array}$ & $\begin{array}{c}0.033 \\
(0.124)\end{array}$ & $\begin{array}{c}0.252^{*} \\
(0.146)\end{array}$ & $\begin{array}{c}0.021 \\
(0.214)\end{array}$ \\
\hline College & $\begin{array}{l}0.203^{* * *} \\
(0.057)\end{array}$ & $\begin{array}{c}0.155 \\
(0.119)\end{array}$ & $\begin{array}{c}0.101 \\
(0.103)\end{array}$ & $\begin{array}{c}0.164 \\
(0.125)\end{array}$ & $\begin{array}{l}0.354^{* *} \\
(0.145)\end{array}$ & $\begin{array}{c}0.126 \\
(0.213)\end{array}$ \\
\hline Univ. & $\begin{array}{l}0.172^{* * *} \\
(0.059)\end{array}$ & $\begin{array}{c}0.143 \\
(0.144)\end{array}$ & $\begin{array}{c}0.035 \\
(0.116)\end{array}$ & $\begin{array}{l}0.264^{* *} \\
(0.13)\end{array}$ & $\begin{array}{c}0.248^{*} \\
(0.147)\end{array}$ & $\begin{array}{c}0.013 \\
(0.209)\end{array}$ \\
\hline С 1930-1939 & $\begin{array}{c}-1.089^{* * *} \\
(0.088)\end{array}$ & & & & & \\
\hline C 1940-1949 & $\begin{array}{c}-1.038^{* * *} \\
(0.08)\end{array}$ & & & & & \\
\hline C 1950-1959 & $\begin{array}{c}-0.871^{* * *} \\
(0.075)\end{array}$ & & & & & \\
\hline C 1960-1969 & $\begin{array}{c}-0.651^{* * *} \\
(0.073)\end{array}$ & & & & & \\
\hline С 1970-1979 & $\begin{array}{c}-0.342^{* * *} \\
(0.073)\end{array}$ & & & & & \\
\hline \multicolumn{7}{|c|}{ Time-varying } \\
\hline Parental & $\begin{array}{l}0.03^{* * *} \\
(0.003)\end{array}$ & $\begin{array}{l}0.017^{* *} \\
(0.009)\end{array}$ & $\begin{array}{l}0.018^{* * *} \\
(0.006)\end{array}$ & $\begin{array}{l}0.035^{* * *} \\
(0.005)\end{array}$ & $\begin{array}{l}0.038^{* * *} \\
(0.004)\end{array}$ & $\begin{array}{l}0.072^{* * *} \\
(0.008)\end{array}$ \\
\hline Observations & 9957 & 952 & 1478 & 2118 & 2540 & 2222 \\
\hline log likelihood & $-58,513$ & -4727 & -7530 & $-11,106$ & $-13,558$ & -9541 \\
\hline
\end{tabular}

Notes: Standard errors are in parentheses. ${ }^{*},{ }^{* *}$, and ${ }^{* * *}$ denote $1 \%, 5 \%$, and $10 \%$ level of significance, respectively. C 1930-1939 refers to the 1930-1939 birth cohort, similarly, the C 1940-1949 to C 1970-1979 refer to the birth cohort 1940-1949 to 1970-1979. 
respectively. In total sample estimation (column 1 in both tables) the coefficients on the cohort effects are highly significant. It should be noted that these cohort effects are not proportional at all points of the employment duration distribution, but can be interpreted as cohort average effects. For both men and women the coefficients are negative, indicating a decreasing hazard of leaving employment for each of the cohorts considered when compared to those born in subsequent years. For both genders the cohort effects point to a larger hazard for more recent cohorts. This can be seen as a decreasingly negative coefficient for succeeding cohorts of both men and women.

Overall assessments of fit for the re-estimated model are performed using a comparison of the Cox-Snell residuals to the standard exponential distribution with $\lambda(t)=1$. These plots are found in Figure 7 and Figure 8 for men and women respectively. A perfectly fitting model would generate a plot that lies directly on top of the diagonal line. The figures seem to imply that the model results are quite poor for latter cohorts of men and earlier cohorts of women. However, in Table 9 it is shown that the portion of the residual plots with a poor fit (chosen by visual inspection of the Cox-Snell residual plots) is relegated to a number of outlying observations and that, for the most part, these entail fewer than $1 \%$ of observations. Men of the post 1940s cohorts and women of the post 1950s cohorts have between $1 \%$ and $5 \%$ of their residuals falling significantly out of line. It should be noted that censoring in the right tails of the employment duration distribution will generate errors around the tails of the Cox-Snell residual plots.

For men, it can be observed that being married prior to the commencement of the employment spell decreases the hazard in some instances. For women this is true until the 1970s cohort, where marriage raises the hazard.
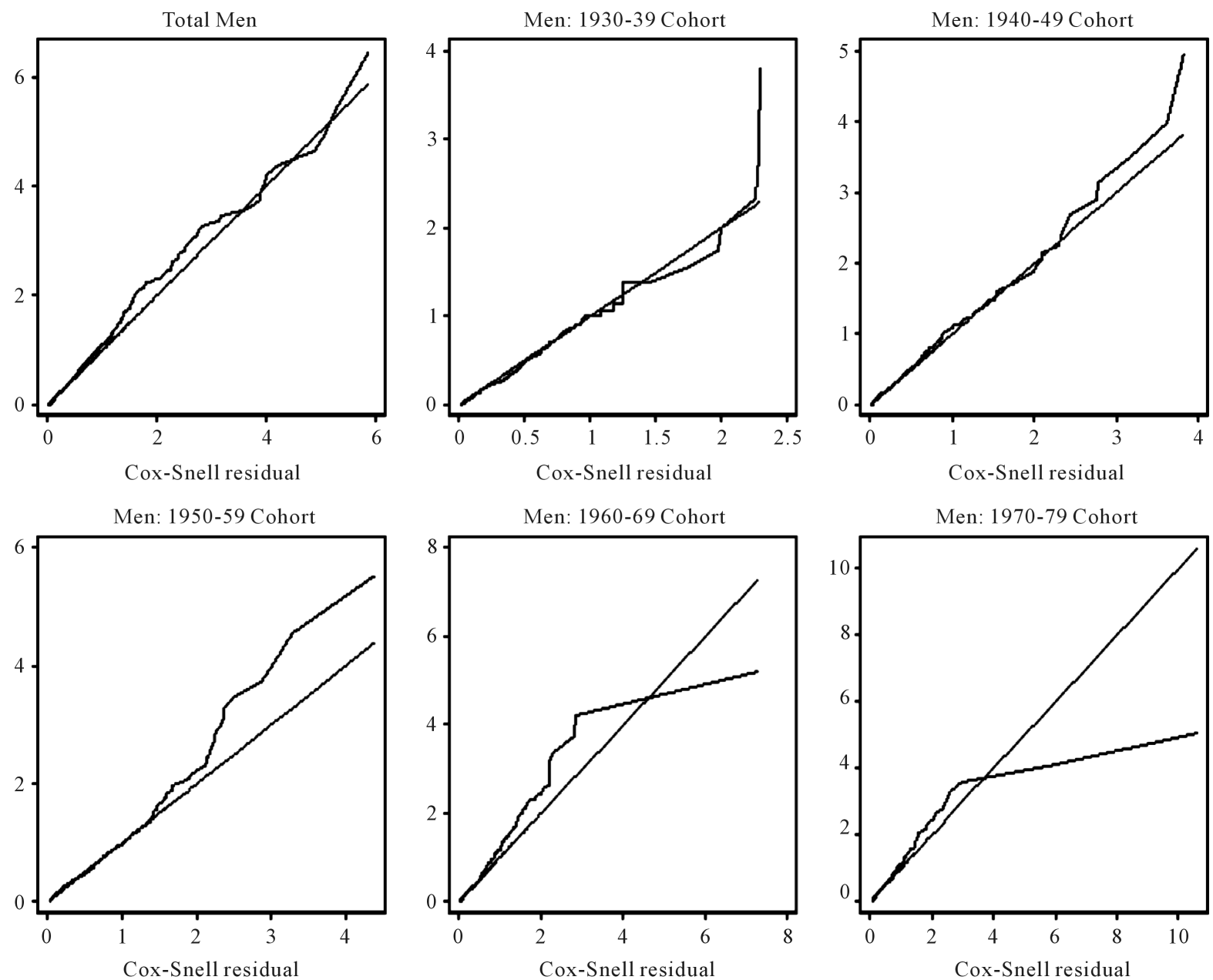

Note: The Cox-Snell residual plots above are displayed for the total sample and by birth cohort. 


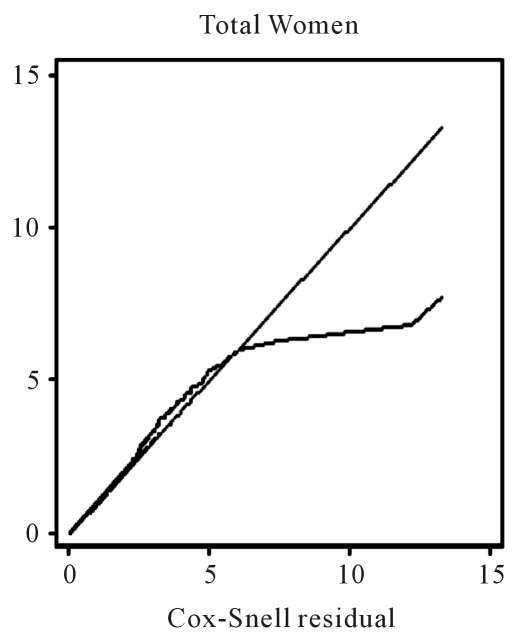

Women: 1950-59 Cohort

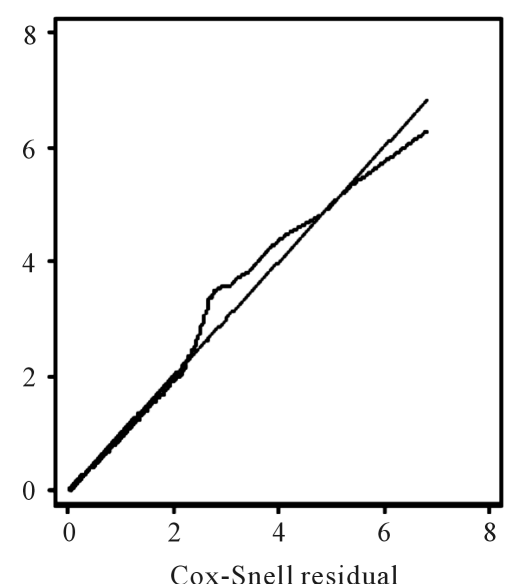

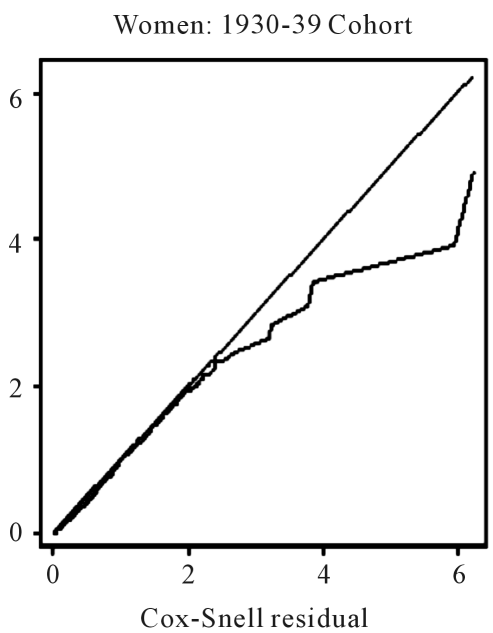

Women: 1960-69 Cohort

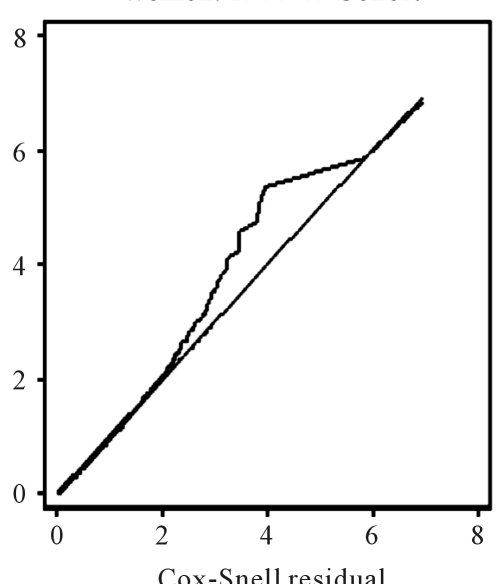

Women: 1940-49 Cohort

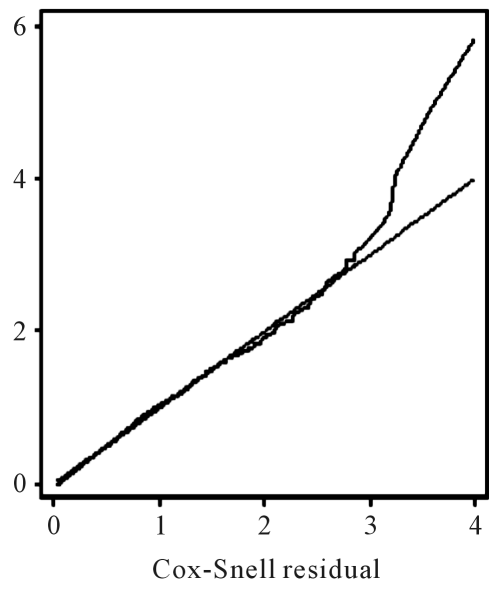

Women: 1970-79 Cohort

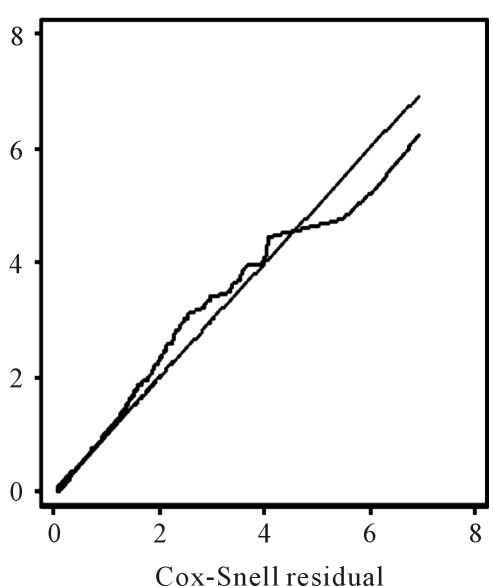

Note: The Cox-Snell residual plots above are displayed for the total sample and by birth cohort.

Figure 8. Cox-Snell residual plots: Women.

Table 9. Cox-Snell residual shares.

\begin{tabular}{ccc}
\hline & Cut-off value & Proportion below cutoff \\
\hline Men total & 6 & 1.0000 \\
Men 1930-1939 & 2 & 0.9925 \\
Men 1940-1949 & 3 & 0.9971 \\
Men 1950-1959 & 2 & 0.988 \\
Men 1960-1969 & 1 & 0.9671 \\
Men 1970-1979 & 1 & 0.9767 \\
Women total & 5 & 0.9995 \\
Women 1930-1939 & 3 & 0.9958 \\
Women 1940-1949 & 2.5 & 0.9912 \\
Women 1950-1959 & 3 & 0.9958 \\
Women 1960-1969 & 2 & 0.965 \\
Women 1970-1979 & 1.5 & 0.9536 \\
\hline
\end{tabular}

Notes: The table presents the proportion of residual values which fall below a selected cut-off deemed appropriate from examination of the Cox-Snell Residual plots in Figure 7 and Figure 8. 
This is likely a selection issue for women of earlier cohorts as it was generally the case that young women would enter the labour market until marriage. This social convention likely no longer held sway by the time women of the 1970s cohort had entered the labour market. The coefficient on the age at which work began also switched signs for women in the 1970s cohort. This set of changes coincides with the major shift of women into the workforce that occurred for cohorts of women born during and after the 1960s. Immigration also reduces the hazard for men born in the 1940s and 1950s and most cohorts of women.

For those leaving employment for work-related reasons (like plant closures or layoffs) there is a significant increase to the hazard for both men and women. The most prominent rise in the contribution to the hazard is for those who were born in the 1970s, the coefficient for the 1970s cohort increases significantly for women and is more than doubled for men. These increases are likely due to the recession of the 1990s when layoffs and unemployment rates spiked and a jobless recovery ensued (the prolonged weakness in the labour market made a separation of over three months more likely). By including a cyclical proxy in the form of the unemployment rate gap at the time of exit, cyclical effects can be controlled-leaving the coefficient on work related separation one which represents the institutional shifts that affected those born in the 1970s (it should be noted that there is some weak correlation between these two variables $\rho \approx 0.15$ ). But the impacts of macro conditions and work related departures consistently raise the hazard in an increasing fashion across cohorts up to the 1960s cohort. Both coefficients show a discontinuous jump between the 1960s and 1970s cohorts implying that work related departures and macroeconomic conditions had a joint effect for workers of the 1970s cohort. These findings are consistent with the findings of Ostrovsky [19] regarding the effects of recessions on earnings stability.

There is always an increase in the hazard for departures due to parental reasons. For women, a larger increase in the size of the coefficient on parental separations can be seen associated with the 1950s and the 1970s birth cohort. These may be partly due to the increased generosity of maternity leave provisions in the unemployment insurance program reforms instituted in 1971 (when 15 weeks of maternity leave could be claimed through unemployment insurance) and the increases to leave provisions in 1990. The 1990 provisions provided 10 weeks of parental leave (expanded to 35 weeks in 2001), this coincides with the increase to the hazard observed for women born in the 1970s.

Interestingly, the coefficients on the education levels contribute negatively to the hazard for men but positively for women. However, the effects of education are largely insignificant for women by cohort and only exert influence in the 1950s and 1960s cohorts. These results are in line with Farber [8] who found that increasing education levels mitigated tenure declines only to a small degree. For men, university level educational attainment is found to be significant from the 1940s until the 1960s cohort. For those born in the 1970s the contributions of education disappear.

\subsection{Competing Risks Regression Results}

To further analyze the possibility that the effects of recessionary periods and parental provisions are effective for men and women respectively a competing risks analysis was run for both sub-groups, again by cohort. For men, the sub-hazard under analysis was that of separating from employment by way of a work related separation with competing risks of separating for family-related or personal reasons. For women, the sub-hazard under analysis was that of a separation induced by separation due to the birth of a child (or adoption) with competing risks of separations for other personal, family related or work related reasons.

The results of the competing risks regressions can be seen in Table 10 and Table 11. For men the aggregate sub-hazard of separation due to work related reasons is reduced if the individual is married or an immigrant. The hazard falls with higher levels of education and for earlier cohorts of workers. Declines in the hazard are only found for workers of the 1950s cohort and earlier. Adverse macroeconomic conditions at separation increase the hazard, the effects are strongest for the 1960s and 1970s cohorts. This suggests that macroeconomic conditions had a significant impact on separations for men due to work related reasons at the same time that institutional factors (proxied by cohort effects in the aggregate equation) contributed to a rising hazard for these workers. For women, the sub-hazard of separation due to parental/maternity based departures is negatively influenced by the age at which work began and positively influenced by the unemployment rate gap and educational attainment. Furthermore, the sub-hazard rises for cohorts after the 1950s. This implies that women born in the 1970s had a greater risk of separation for maternity reasons than succeeding or preceding cohort of women. This strange result is likely due to delays in the average age of having children in later cohorts and the fact that at the time of 
Table 10. Competing risks regression (work related separation vs. other reasons): Men.

\begin{tabular}{|c|c|c|c|c|c|c|}
\hline & Total sample & C 1930-1939 & C 1940-1949 & C 1950-1959 & С 1960-1969 & C $1970-1979$ \\
\hline Part-time & $\begin{array}{c}-0.447 \\
(0.35)\end{array}$ & $\begin{array}{c}-17.26^{* * *} \\
(0.43)\end{array}$ & $\begin{array}{c}-16.782^{* * *} \\
(0.375)\end{array}$ & $\begin{array}{l}-1.781^{*} \\
(1.052)\end{array}$ & $\begin{array}{l}-0.239 \\
(0.557)\end{array}$ & $\begin{array}{l}0.16 \\
(0.5)\end{array}$ \\
\hline Married & $\begin{array}{c}-0.337^{* *} \\
(0.152)\end{array}$ & $\begin{array}{l}-0.104 \\
(0.545)\end{array}$ & $\begin{array}{c}-0.821^{* * *} \\
(0.372)\end{array}$ & $\begin{array}{c}-0.749^{* * * *} \\
(0.282)\end{array}$ & $\begin{array}{c}0.145 \\
(0.271)\end{array}$ & $\begin{array}{c}-0.141 \\
(0.39)\end{array}$ \\
\hline Age began & $\begin{array}{l}0.022^{*} \\
(0.011)\end{array}$ & $\begin{array}{c}0.049 \\
(0.033)\end{array}$ & $\begin{array}{c}0.027 \\
(0.039)\end{array}$ & $\begin{array}{l}0.033^{*} \\
(0.018)\end{array}$ & $\begin{array}{c}0.01 \\
(0.019)\end{array}$ & $\begin{array}{c}0.042 \\
(0.031)\end{array}$ \\
\hline Immigrant & $\begin{array}{c}-0.197^{* *} \\
(0.096)\end{array}$ & $\begin{array}{c}0.072 \\
(0.419)\end{array}$ & $\begin{array}{l}-0.118 \\
(0.256)\end{array}$ & $\begin{array}{c}-0.356^{*} \\
(0.187)\end{array}$ & $\begin{array}{l}-0.193 \\
(0.161)\end{array}$ & $\begin{array}{l}-0.056 \\
(0.238)\end{array}$ \\
\hline UR gap & $\begin{array}{l}0.456^{* * *} \\
(0.069)\end{array}$ & $\begin{array}{l}0.519^{* *} \\
(0.22)\end{array}$ & $\begin{array}{c}0.258 \\
(0.197)\end{array}$ & $\begin{array}{l}0.353^{* * *} \\
(0.122)\end{array}$ & $\begin{array}{l}0.609^{* * *} \\
(0.135)\end{array}$ & $\begin{array}{l}0.638^{* * *} \\
(0.192)\end{array}$ \\
\hline High school & $\begin{array}{c}-0.308^{* *} \\
(0.149)\end{array}$ & $\begin{array}{c}-1.182^{* * *} \\
(0.449)\end{array}$ & $\begin{array}{c}0.085 \\
(0.408)\end{array}$ & $\begin{array}{l}-0.307 \\
(0.279)\end{array}$ & $\begin{array}{c}-0.583^{* *} \\
(0.284)\end{array}$ & $\begin{array}{c}0.26 \\
(0.545)\end{array}$ \\
\hline College & $\begin{array}{l}-0.3^{* *} \\
(0.152)\end{array}$ & $\begin{array}{c}-1.114^{* *} \\
(0.504)\end{array}$ & $\begin{array}{c}0.536 \\
(0.392)\end{array}$ & $\begin{array}{l}-0.298 \\
(0.286)\end{array}$ & $\begin{array}{c}-0.763^{* * * *} \\
(0.291)\end{array}$ & $\begin{array}{c}0.361 \\
(0.547)\end{array}$ \\
\hline University & $\begin{array}{c}-0.614^{* * * *} \\
(0.15)\end{array}$ & $\begin{array}{c}-1.357^{* * *} \\
(0.5)\end{array}$ & $\begin{array}{l}-0.281 \\
(0.406)\end{array}$ & $\begin{array}{c}-0.734^{* * * *} \\
(0.283)\end{array}$ & $\begin{array}{c}-0.627^{* *} \\
(0.281)\end{array}$ & $\begin{array}{l}-0.072 \\
(0.546)\end{array}$ \\
\hline С 1930-1939 & $\begin{array}{c}-1.645^{* * *} \\
(0.265)\end{array}$ & & & & & \\
\hline С 1940-1949 & $\begin{array}{c}-1.182^{* * *} \\
(0.231)\end{array}$ & & & & & \\
\hline C 1950-1959 & $\begin{array}{c}-0.518^{* *} \\
(0.216)\end{array}$ & & & & & \\
\hline С 1960-1969 & $\begin{array}{c}-0.244 \\
(0.21)\end{array}$ & & & & & \\
\hline C 1970-1979 & $\begin{array}{l}-0.174 \\
(0.214)\end{array}$ & & & & & \\
\hline Observations & 7120 & 521 & 1015 & 1479 & 1925 & 1658 \\
\hline log likelihood & -7843 & -280 & -770 & -1709 & -2219 & -1289 \\
\hline
\end{tabular}

Notes: Standard errors are in parentheses. ${ }^{*},{ }^{* *}$, and ${ }^{* * *}$ denote $1 \%, 5 \%$, and $10 \%$ level of significance, respectively. C $1930-1939$ refers to the 1930-1939 birth cohort, similarly, the C 1940-1949 to C 1970-1979 refer to the birth cohort 1940-1949 to 1970-1979.

the 2006 GSS women born in 1980 would be reaching age 26 (and 21 for the 2001 GSS). This combined effect may be the reason for this result. Nevertheless, the cohort pattern is consistent with the hypothesis that maternity-based separations increase in line with the introduction of new support measures.

The combined results above show that major changes occurred for both men and women born into the 1970s cohort due to changing work conditions. Parental provisions also powerfully impacted the ability of women to break up their employment spells and return to the same job in the future for both the 1950s and 1970s cohort. For men starting in the 1950s cohort and women after the 1960s cohort, holding part time work was strongly associated with increases in the hazard. The rise of such alternative work arrangements likely contributed to rising rates of work interruption due to weaker labour market attachment for these individuals.

\section{Conclusions}

Employment tenures of workers have declined over time and a number of socio-economic factors have contributed to this phenomena. It has been shown above that successive cohorts of workers have had increasingly 
Table 11. Competing risks regression (maternity/parental related separation vs. other reasons): Women.

\begin{tabular}{|c|c|c|c|c|c|c|}
\hline & Total sample & C 1930-1939 & C 1940-1949 & C 1950-1959 & C 1960-1969 & C $1970-1979$ \\
\hline Part-time & $\begin{array}{l}-0.134 \\
(0.121)\end{array}$ & $\begin{array}{l}-0.99 \\
(1.04)\end{array}$ & $\begin{array}{l}-0.783 \\
(0.541)\end{array}$ & $\begin{array}{l}-0.274 \\
(0.307)\end{array}$ & $\begin{array}{l}-0.008 \\
(0.212)\end{array}$ & $\begin{array}{c}0.012 \\
(0.192)\end{array}$ \\
\hline Married & $\begin{array}{l}-0.003 \\
(0.094)\end{array}$ & $\begin{array}{c}-1.264^{* * *} \\
(0.476)\end{array}$ & $\begin{array}{c}-0.23 \\
(0.296)\end{array}$ & $\begin{array}{l}-0.156 \\
(0.179)\end{array}$ & $\begin{array}{l}-0.123 \\
(0.157)\end{array}$ & $\begin{array}{l}0.656^{* * *} \\
(0.167)\end{array}$ \\
\hline Age began & $\begin{array}{c}-0.069^{* * *} \\
(0.007)\end{array}$ & $\begin{array}{l}-0.032 \\
(0.021)\end{array}$ & $\begin{array}{c}-0.088^{* * *} \\
(0.019)\end{array}$ & $\begin{array}{c}-0.081^{* * *} \\
(0.015)\end{array}$ & $\begin{array}{c}-0.053^{* * *} \\
(0.012)\end{array}$ & $\begin{array}{l}-0.01 \\
(0.017)\end{array}$ \\
\hline Immigrant & $\begin{array}{l}-0.107^{*} \\
(0.061)\end{array}$ & $\begin{array}{c}0.158 \\
(0.219)\end{array}$ & $\begin{array}{l}-0.142 \\
(0.162)\end{array}$ & $\begin{array}{c}-0.113 \\
(0.12)\end{array}$ & $\begin{array}{c}-0.1 \\
(0.109)\end{array}$ & $\begin{array}{l}-0.227^{*} \\
(0.134)\end{array}$ \\
\hline UR gap & $\begin{array}{l}0.063^{* *} \\
(0.027)\end{array}$ & $\begin{array}{c}0.023 \\
(0.093)\end{array}$ & $\begin{array}{l}-0.056 \\
(0.086)\end{array}$ & $\begin{array}{c}0.034 \\
(0.049)\end{array}$ & $\begin{array}{l}0.17^{* * *} \\
(0.047)\end{array}$ & $\begin{array}{l}-0.029 \\
(0.091)\end{array}$ \\
\hline High sch. & $\begin{array}{l}0.586^{* * *} \\
(0.152)\end{array}$ & $\begin{array}{c}0.287 \\
(0.322)\end{array}$ & $\begin{array}{l}0.556^{*} \\
(0.33)\end{array}$ & $\begin{array}{l}0.227 \\
(0.3)\end{array}$ & $\begin{array}{l}0.841^{* *} \\
(0.342)\end{array}$ & $\begin{array}{c}0.98^{*} \\
(0.501)\end{array}$ \\
\hline College & $\begin{array}{l}0.851^{* * *} \\
(0.151)\end{array}$ & $\begin{array}{l}0.596^{*} \\
(0.309)\end{array}$ & $\begin{array}{l}0.769^{* *} \\
(0.326)\end{array}$ & $\begin{array}{l}0.518^{*} \\
(0.301)\end{array}$ & $\begin{array}{l}0.989^{* * *} \\
(0.339)\end{array}$ & $\begin{array}{l}1.346^{* * *} \\
(0.498)\end{array}$ \\
\hline Univ. & $\begin{array}{l}0.889^{* * * *} \\
(0.152)\end{array}$ & $\begin{array}{l}0.218 \\
(0.37)\end{array}$ & $\begin{array}{l}0.755^{* *} \\
(0.345)\end{array}$ & $\begin{array}{l}0.84^{* * *} \\
(0.306)\end{array}$ & $\begin{array}{l}1.018^{* * * *} \\
(0.335)\end{array}$ & $\begin{array}{l}1.127^{* *} \\
(0.496)\end{array}$ \\
\hline С 1930-1939 & $\begin{array}{l}-0.012 \\
(0.182)\end{array}$ & & & & & \\
\hline C $1940-1949$ & $\begin{array}{c}0.14 \\
(0.168)\end{array}$ & & & & & \\
\hline C 1950-1959 & $\begin{array}{l}0.441^{* * *} \\
(0.161)\end{array}$ & & & & & \\
\hline С 1960-1969 & $\begin{array}{l}0.635^{* * *} \\
(0.159)\end{array}$ & & & & & \\
\hline C 1970-1979 & $\begin{array}{l}0.674^{* * *} \\
(0.161)\end{array}$ & & & & & \\
\hline Observations & 9877 & 944 & 1462 & 2096 & 2527 & 2206 \\
\hline log Likelihood & $-23,505$ & -1124 & -2287 & -4791 & -6556 & -4291 \\
\hline
\end{tabular}

Notes: Standard errors are in parentheses. ${ }^{*},{ }^{* *}$, and ${ }^{* * *}$ denote $1 \%, 5 \%$, and $10 \%$ level of significance, respectively. C $1930-1939$ refers to the 1930-1939 birth cohort, similarly, the C 1940-1949 to C 1970-1979 refer to the birth cohort 1940-1949 to 1970-1979.

shorter first employment durations. This pattern has occurred for both men and women, but the decline has been far more prominent for men. The cohorts of workers who were born in the 1970s were likely to be strongly affected by the recession of 1990s and its ensuing jobless recovery, and this shows up as increasing hazards for both groups. Parental leave increases the probability of separation strongly for women and the increasing hazard by cohort coincides with the increasing generosity of parental benefit provisions. It is likely that this fact plays a large role in explaining the divergence of employment tenures from job tenures as maternity provisions allowed women to break up employment without separating from their jobs in the post 1970 period. Work related issues also increase the probability of separations, even when the business cycle is taken into consideration. This likely implies that the firm's shutdown and layoffs, particularly with regard to the 1970-1979 cohort of workers, have significantly altered the stability of employment for men and women.

Overall, these data imply that there has been a decline in employment stability. The paper contributes to the employment stability literature by analyzing five birth cohorts using the GSS data. The use of these retrospective data allows us to compare the trends in employment and job stability and find that the relationship has changed 
over time. In particular, institutional factors have likely contributed to preserving the stability of job tenures while decreasing the stability of continuous employment (which, in the case of parental leave, is likely an improvement rather than impediment to the general welfare). To extend this study it would be preferable to include all employment spells to follow workers across multiple employment periods. Likewise, it would be important to do further investigation of the differences between the LFS and GSS using matching estimators to compare the surveys. Further exploration of memory effects could also be undertaken using the 25th cycle of the GSS which would permit an examination of memory effects over a 10-year period for employment durations. Finally, to examine issues surrounding maternity leave provisions, it would be interesting to compare changes in the Canadian GSS against changes which occurred in the US over the same period (as there are time-use GSS data available for the US).

\section{References}

[1] Hall, R.E. (1982) The Importance of Lifetime Jobs in the U.S. Economy. American Economic Review, 72, 716-724.

[2] Diebold, F.X., Neumark, D. and Polsky, D. (1994) Job Stability in the United States. Journal of Labor Economics, 15, 206-233.

[3] Farber, H.S. (1995) Are Lifetime Jobs Disappearing? Job Duration in the United States: 1973-1993. NBER Working Paper No. W5014.

[4] Jaeger, D.A. and Stevens, A.H. (1999) Is Job Stability in the United States Falling? Reconciling Trends in the Current Population Survey and Panel Study of Income Dynamics. Journal of Labor Economics, 17, S1-S28. http://dx.doi.org/10.1086/209941

[5] Swinnerton, K.A. and Wial, H. (1995) Is Job Stability Declining in the U.S. Economy? Industrial and Labor Relations Review, 48, 293-304. http://dx.doi.org/10.2307/2524488

[6] Ureta, M. (1992) The Importance of Lifetime Jobs in the U.S. Economy, Revisited. American Economic Review, 82, 322-335.

[7] Rose, S.J. (1995) Declining Job Security and the Professionalization of Opportunity. National Commission for Employment Policy Research Report No. 95-04.

[8] Farber, H.S. (2007) Is the Company Man an Anachronism? Trends in Long Term Employment in the U.S., 1973-2006. Princeton University Industrial Relations Section Working Paper \#518, Princeton.

[9] Green, D.A. and Riddell, W.C. (1997) Job Durations in Canada: Is Long Term Employment Declining? In: Abbott, M.G., Beach, C.M. and Chaykowski, R.P., Eds., Transition and Structural Change in the North American Labour Market, IRC Press, Kingston.

[10] Picot, G., Heisz, A. and Nakamura, A. (2001) Worker Mobility, Hiring and the Youth Labour Market during the 1990s. Analytical Studies Branch Research Paper Series No. 155, Statistics Canada, Ottawa.

[11] Heisz, A. (2005) The Evolution of Job Stability in Canada: Trends and Comparisons with U.S. Results. Canadian Journal of Economics, 38, 105-127. http://dx.doi.org/10.1111/j.0008-4085.2005.00271.x

[12] Brochu, P. (2013) The Source of the New Canadian Job Stability Patterns. Canadian Journal of Economics, 46, 412440.

[13] Ignaczak, L. and Voia, M. (2011) A Retrospective Analysis of Employment Duration: Evidence from the Second Half of the Twentieth Century. Labour, 25, 97-125. http://dx.doi.org/10.1111/j.1467-9914.2010.00512.x

[14] Christofides, L.N. and McKenna, C.J. (1993) Employment Flows and Job Tenure in Canada. Canadian Public Policy, 19, 145-161.

[15] Torelli, N. and Trivellato, U. (1993) Modeling Inaccuracies in Job Search Duration Data. Journal of Econometrics, 59, 187-211. http://dx.doi.org/10.1016/0304-4076(93)90045-7

[16] Fine, J. and Gray, R. (1999) A Proportional Hazards Model for the Subdistribution of a Competing Risk. Journal of the American Statistical Association, 94, 496-509. http://dx.doi.org/10.1080/01621459.1999.10474144

[17] Zorn, C. (2000) Modeling Duration Dependence. Political Analysis, 8, 367-380. http://dx.doi.org/10.1093/oxfordjournals.pan.a029821

[18] Fisher, L.D. and Lin, D.Y. (1999) Time-Dependent Covariates in the Cox Proportional-Hazards Regression Model. Annual Review of Public Health, 20, 145-157.

[19] Ostrovsky, Y. (2010) Long-Run Earnings Inequality and Earnings Instability among Canadian Men Revisited, 19852005. The B.E. Journal of Economic Analysis \& Policy, 10, 1-32. 